\title{
Impaired Repression at a 5-Hydroxytryptamine 1A Receptor Gene Polymorphism Associated with Major Depression and Suicide
}

\author{
Sylvie Lemonde, ${ }^{1}$ Gustavo Turecki, ${ }^{2}$ David Bakish, ${ }^{3}$ Lisheng Du, ${ }^{3}$ Pavel D. Hrdina, ${ }^{3}$ Christopher D. Bown, ${ }^{1}$ \\ Adolfo Sequeira, ${ }^{2}$ Neena Kushwaha, ${ }^{1}$ Stephen J. Morris, ${ }^{1}$ Ajoy Basak, ${ }^{4}$ Xiao-Ming Ou, ${ }^{1}$ and Paul R. Albert ${ }^{1}$ \\ ${ }^{1}$ Ottawa Health Research Institute (Neuroscience), University of Ottawa, Departments of Medicine and Cellular and Molecular Medicine, Ottawa, Canada, \\ K1H 8M5, 2 Douglas Hospital Research Center, McGill University, Montreal, Canada H4M-1R3, ${ }^{3}$ Institute for Mental Health Research, Royal Ottawa \\ Hospital, Ottawa, Canada K1Z-7K4, and ${ }^{4}$ Loeb Research Building, Ottawa Health Research Institute, Ottawa, Canada K1Y-4E9
}

Inhibition of serotonergic raphe neurons is mediated by somatodendritic 5-HT1A autoreceptors, which may be increased in depressed patients. We report an association of the C(-1019)G 5-HT1A promoter polymorphism with major depression and suicide in separate cohorts. In depressed patients, the homozygous $\mathrm{G}(-1019)$ allele was enriched twofold versus controls $(p=0.0017$ and 0.0006 for $\mathrm{G} / \mathrm{G}$ genotype and $\mathrm{G}$ allele distribution, respectively), and in completed suicide cases the $\mathrm{G}(-1019)$ allele was enriched fourfold ( $p=0.002$ and 0.00008 for $\mathrm{G} / \mathrm{G}$ genotype and $\mathrm{G}$ allele distribution, respectively). The $\mathrm{C}(-1019)$ allele was part of a 26 bp imperfect palindrome that bound transcription factors nuclear NUDR [nuclear deformed epidermal autoregulatory factor (DEAF-1)]/suppressin and Hairy/Enhancer-ofsplit-5 (Drosophila) (Hes5) to repress 5-HT1A or heterologous promoters, whereas the G(-1019) allele abolished repression by NUDR, but only partially impaired Hes5-mediated repression. Recombinant NUDR bound specifically to the 26 bp palindrome, and endogenous NUDR was present in the major protein-DNA complex from raphe nuclear extracts. Stable expression of NUDR in raphe cells reduced levels of endogenous 5-HT1A protein and binding. NUDR protein was colocalized with 5-HT1A receptors in serotonergic raphe cells, hippocampal and cortical neurons, and adult brain regions including raphe nuclei, indicating a role in regulating 5-HT1A autoreceptor expression. Our data indicate that NUDR is a repressor of the 5-HT1A receptor in raphe cells the function of which is abrogated by a promoter polymorphism. We suggest a novel transcriptional model in which the G(-1019) allele derepresses 5-HT1A autoreceptor expression to reduce serotonergic neurotransmission, predisposing to depression and suicide.

Key words: promoter; polymorphism; major depression; suicide; serotonin; transcription

\section{Introduction}

The serotonin system of the brain originates from neurons of the raphe nuclei that project widely throughout the brain to innervate various cortical, limbic, and hypothalamic areas that are involved in regulation of mood, emotion, stress, etc. (Törk, 1990; Jacobs and Azmitia, 1992). Reduced serotonergic neurotransmission is implicated in the pathogenesis of depressive illnesses and suicidal behaviors (Doris et al., 1999; Mann, 1999). Negative feedback inhibition of serotonergic raphe neurons is mediated by somatodendritic 5-HT1A autoreceptors (Mongeau et al., 1997; Pineyro and Blier, 1999). Several antidepressant compounds de-

\footnotetext{
Received May 2, 2003; revised Aug. 11, 2003; accepted Aug. 12, 2003.

This research was supported by Canadian Institutes of Health Research (CIHR) (P.R.A., G.T.), the Ontario Mental Health Foundation (OMHF) (P.R.A.), and the Royal Ottawa Hospital Foundation (P.D.H., L.D., D.B.). S.L. and N.K. hold studentships from the CIHR; G.T. is a CIHR scholar; C.B. and X.O. hold a fellowship from the OMHF; P.R.A. holds the Novartis/CIHR Michael Smith Chair in Neuroscience. We acknowledge Dr. William Staines, Mireille Daigle, Pierre Fréchette, Dr. Charlie Thompson, Ava Chow, and Cynthia Hooper for excellent technical assistance.

Correspondence should be addressed to Paul R. Albert, Ottawa Health Research Institute (Neuroscience), University of Ottawa, Departments of Medicine and Cellular and Molecular Medicine, 451 Smyth Road, Ottawa, Canada, K1H 8M5. E-mail: palbert@uottawa.ca.

S. J. Morris's present address: Aegera Therapeutics Inc., Montreal, Canada H3E-1A8.

X.-M. Ou's present address: School of Pharmacy, University of Southern California, Los Angeles, CA 90089-9121. Copyright $\odot 2003$ Society for Neuroscience $\quad$ 0270-6474/03/238788-12\$15.00/0
}

sensitize raphe 5-HT1A autoreceptors resulting in enhanced 5-HT neurotransmission (Albert et al., 1996; Artigas et al., 1996; Pineyro and Blier, 1999). Conversely, postmortem brains from depressed suicide victims versus nondepressed control individuals display elevated 5-HT1A receptor density in the raphe nuclei but not at postsynaptic sites (Stockmeier et al., 1998), which would decrease serotonergic activity in depressed patients.

Given the high lifetime prevalence of major depression of 16.1\% (Doris et al., 1999; Hyman, 2000; Nestler et al., 2002), this illness is likely to involve multiple genetic loci, complicating linkage analysis. In an alternate approach, polymorphisms identified in candidate genes have been correlated with traits of mental illness. The short allele of the long polymorphic repeat of the serotonin transporter gene has been associated with reduced transcriptional activity and anxiety-related behavior in humans (Lesch et al., 1996), whereas the long allele is associated with obsessive-compulsive disorder (Bengel et al., 1999) and completed suicide (Du et al., 1999). Polymorphisms identified in the 5-HT1A receptor gene have yet to be associated with mental illness (Erdmann et al., 1995; Nakhai et al., 1995; Kawanishi et al., 1998; Wu and Comings, 1999; Arias et al., 2002). The C(-1019)G polymorphism of the 5 -HT1A receptor gene is prevalent in the 
normal population (Wu and Comings, 1999) and is located in a region associated with significant repressor activity (S. Lemonde, unpublished observations). We hypothesized that variation in the sequence of the repressor region could lead to impaired repression of the 5-HT1A receptor and might correlate with depression or suicidal behavior or both (Albert et al., 1996).

\section{Materials and Methods Clinical samples}

Major depression. Blood samples were obtained from a total of 129 (53 males; age $43 \pm 11$ years; 95\% Caucasian) unrelated patients and 134 (55 males; age $36 \pm 12$ years; $96 \%$ Caucasian) normal healthy volunteers recruited by local advertising or from a random pool of individuals. Patients suffering from major depressive disorder (unipolar) were selected from those attending the Royal Ottawa Hospital Psychopharmacology Unit as described (Du et al., 2000), and bipolar patients were excluded. Briefly, the Diagnostic and Statistical Manual of Mental Disorders (DSM-IV) criteria for major depression were used. Only subjects with a minimal score of 18 on the Hamilton Rating Scale for Depression (17 items), which is consistent with moderately severe clinical depression, were included in this study. All control subjects were asked to complete a self-rating Beck's Depression Inventory, had no history of serious medical or mental illness, were drug free, and had no family history of psychiatric illness. According to origin, gender, and age, subjects from the patient and control groups were comparable, and all were from the Ontario area. Exclusion of non-Caucasian samples did not alter the conclusion that was drawn. Genotype distribution in both samples was in Hardy-Weinberg equilibrium.

Suicide completers. Consecutive cases of suicide were collected as part of an ongoing collaboration with the coroner's office of Quebec. Controls for the suicide study were living subjects without a history of suicidal behavior or a major psychiatric diagnosis. A total of 102 suicide completers (98 males) and 116 normal controls (116 males) were investigated. The mean ages were $32.20 \pm 9.38$ and $34 \pm 10.56$ years old, respectively, for suicide cases and controls. Both suicide cases and controls cases were of French-Canadian origin, which is an isolated population with a well characterized founder effect (Heyer and Tremblay, 1995). All subjects included in this study (or their families, for suicide cases) provided written informed consent, as approved by the local Institutional Review Board. After consent, DNA was extracted from blood or a tissue sample. Psychological autopsies were performed using a version of the structured clinical interview for DSM-III-R (Spitzer et al., 1992) adapted for interviews with informants. Best-estimate DSM-IV diagnoses were made by a blind panel of psychiatrists and mental health professionals. Forty-three percent $(n=44)$ of the suicide cases had available information on psychiatric diagnoses on the basis of best-estimate psychological autopsies. Of these, $52 \%(n=23)$ met criteria for major depression. Given the low $n$ values, no differences were observed in either allelic $(p=0.63)$ or genotypic $(p=0.82)$ distributions when depressed suicide cases were compared with nondepressed suicides. Detailed diagnostic procedures have been described previously (Lesage et al., 1994).

\section{DNA analysis}

Amplification was between -1595 and -879 bp of the human 5-HT1A gene and was performed in $25 \mu \mathrm{l}$ using $100 \mathrm{ng}$ of genomic DNA, $200 \mu \mathrm{M}$ dNTP, $1 \mathrm{~mm} \mathrm{MgCl}_{2}, 0.5 \mathrm{U}$ of Taq and Pfu, and $2 \mu \mathrm{M}$ primers: 5'GTGGCGACATAAAACCTCA- $3^{\prime}$ and $5^{\prime}$-TTCTTAAATCGTGTCAGCATC-3'. The amplification cycles were as follows: $92^{\circ} \mathrm{C}$ for $5 \mathrm{~min}$; $92^{\circ} \mathrm{C}, 45 \mathrm{sec}, 69^{\circ} \mathrm{C}, 45 \mathrm{sec} ;-0.5^{\circ} \mathrm{C}$ per cycle, $72^{\circ} \mathrm{C}$ for $90 \mathrm{sec}(10 \mathrm{cycles})$; $92^{\circ} \mathrm{C}$ for $45 \mathrm{sec} ; 64^{\circ} \mathrm{C}$ for $45 \mathrm{sec} ; 72^{\circ} \mathrm{C}$ for $90 \mathrm{sec}(30 \mathrm{cycles})$; terminated at $72^{\circ} \mathrm{C}$ for $10 \mathrm{~min}$. The $716 \mathrm{bp}$ PCR product was gel-purified and sequenced (T7 sequencing kit, Amersham Biosciences, Milwaukee, WI). Genotyping of the two sample populations was performed independently by two different laboratories.

\section{Statistical analysis}

$\chi^{2}$ analysis with two-tailed $p$ values was used to compare genotype frequencies between patients and controls and between suicide completers and controls. Allele frequencies were also compared by Fisher's exact test with two-tailed $p$ values. In cell studies, unpaired $t$ tests with two-tailed $p$ values were performed to compare transcriptional activities of the $\mathrm{C}$ versus $G$ alleles, whereas all other statistical significance was obtained by one-way ANOVA analysis with a post hoc Dunnett's test. All of the above statistical analyses were performed using the GraphPad Prism software (San Diego, CA) and calculated using 95\% confidence intervals.

\section{Electrophoretic mobility shift assay}

Nuclear extract preparation and electrophoretic mobility shift assay (EMSA) were done as described (Ou et al., 2000). For EMSA, complementary oligonucleotides from the normal human 5-HT1A sequence were sense -1021/-998 bp 5'-AACGAAGACACACTCGGTCTTCTT3'; antisense $-996 /-1021$ bp 5'-GGAAGAAGACCGAGTGTGTCTTCGTT-3'.

The probe contains the polymorphic site (underlined) and the imperfect palindrome sequence (bold type). The unrelated rat E2F sequence 5'-ATTTAAGTTTCGCGCCTTTTC-3' was used as nonspecific competitor. The ${ }^{32} \mathrm{P}$-labeled probe $(60,000 \mathrm{cpm}$ per sample) was incubated with or without competitor DNA, in $25 \mu \mathrm{l}$ of DNA binding buffer containing $15 \mu \mathrm{g}$ of nuclear protein extract, $2 \mu \mathrm{g}$ of poly (dI-dC) (Sigma, Oakville, $\mathrm{ON}$ ), at room temperature for $20 \mathrm{~min}$. Samples were electrophoresed on a $5 \%$ acrylamide/Tris-glycine gel at $4^{\circ} \mathrm{C}$ for $3 \mathrm{hr}$. For supershift experiments, anti-Hairy/Enhancer-of-split-5 (Drosophila) (Hes5) was used at 1:10 dilution, and anti-nuclear Deformed epidermal autoregulatory factor (DEAF)-1-related protein (NUDR) was used at 1:5 dilution.

\section{Yeast one-hybrid}

Six repeats of the C-allele of the 26 bp element were subcloned into KpnI-XhoI-cut pHISi or SacI-SacII-cut pLacZi vectors (Clontech, Palo Alto, CA), which were linearized by ApaI or AflII digestions, and stably integrated into the YM4271 yeast strain. The transformants were selected on synthetic dropout ${ }^{-}$His, ${ }^{-}$Ura plates containing $20 \mathrm{~mm} 3$-amino1,2,4-triazole for integration of the target-reporter constructs into the HIS3 and URA3 loci. Subsequent transformation with a human brain MATCHMAKER cDNA library (Clontech) fused to GAL4 activation domain and containing a LEU2 selectable marker allowed for selection of transformants on synthetic dropout_His,_Ura,_Leu plates containing $20 \mathrm{~mm}$ 3-amino-1 2,4-triazole. Resistant clones were tested by $\beta$-galactosidase plate assay, retransformed for verification, and sequenced for identification by database search (http://www.ncbi.nlm. nih.gov/BLAST/). To compare $\mathrm{C}$ and $\mathrm{G}$ alleles, six tandem repeats of each were cloned into the pLacZi vector and integrated into YM4271 as described above. Plasmid DNA from clones 76D, 18C, and 33B was transformed into the two yeast strains, and transformants were selected on synthetic dropout_Ura,_Leu plates. Assays of $\beta$-galactosidase activity were done in liquid culture using 4-nitrophenyl $\beta$-D-galactopyranoside as a substrate (Clontech) or by plate assay using 5 -bromo-4-chloro-3indoyl $\beta$-D-galactopyranoside (Duttweiler, 1996).

\section{In vitro transcription/translation and DNase I footprinting}

Recombinant proteins were synthesized using the TNT coupled reticulocyte lysate system (Promega, Madison, WI) and $1 \mu \mathrm{g}$ of the plasmid human (h)NUDR (from ATG to Stop codon) in pcDNA1. The core footprinting system (Promega) was used following manufacturer's recommendations. A gel-purified 434 bp KpnI-BlpI (-1128/-694) DNA fragment was dephosphorylated and labeled with polynucleotide kinase and $\left[\gamma_{-}{ }^{32} \mathrm{P}\right]$ ATP. HincII digestion generated a single end-labeled probe $(20,000 \mathrm{cpm})$ that was preincubated with $0.03,0.15,0.3$, or $0.45 \mathrm{U}$ of RQ1 RNase-free DNase and 0,10 , or $20 \mu \mathrm{g}$ of raphe/midbrain nuclear extract or $3 \mu \mathrm{l}$ of a $25 \mu \mathrm{l}$ preparation of in vitro-transcribed/translated NUDR protein. The reaction products were purified by phenol-chloroform extraction and ethanol precipitation and loaded on a $6 \%$ polyacrylamide sequencing gel with known DNA sequence as position marker.

\section{Antibodies}

Rabbit anti-Hes5 affinity-purified polyclonal antibody was purchased from Chemicon International (Temecula, CA). The hNUDR peptide EAEEPVLSRDEDSEED (amino acids 36-51) was synthesized as a multiple-antigenic peptide and injected in rabbits for production of antibodies (Cedarlane, Hornby, Ontario). NUDR antibody was applied to 
the Affi-Gel blue gel 50-100 mesh, (Bio-Rad Laboratories, Hercules, CA) for albumin removal. Subsequently the antibody was purified by Affi-Gel $15 \mathrm{Gel}$ (Bio-Rad Laboratories) following manufacturer's instructions. Specificity to endogenous NUDR was assessed by Western blot analysis in which a single specific $59 \mathrm{kDa}$ species was identified (Huggenvik et al., 1998 ) and was competed completely by preincubation with $100 \mu \mathrm{g}$ of hNUDR (36-51) peptide. Guinea pig anti-5-HT1A receptor antibody (Chemicon International) was tested for its specificity by Western blotting of extracts $(60 \mu \mathrm{g})$ from rat myoblast L6 cells transfected with vector or the rat 5-HT1A expression plasmid (Lembo and Albert, 1995).

\section{Immunofluorescence}

Immunohistochemistry was performed on rat brain primary cultures, raphe RN46A cells, and $12 \mu \mathrm{m}$ frozen sections from adult male (250-300 gm) Sprague Dawley rat brains. Rats were anesthetized by intraperitoneal injection of $1 \mathrm{ml}$ of somnatol and perfused with saline followed by fresh fixative ( $4 \%$ paraformaldehyde with $0.4 \%$ picric acid in PBS). Animals were decapitated, and brains removed and postfixed overnight at $4^{\circ} \mathrm{C}$ in the same fixative, transferred to $10 \%$ sucrose $/ 0.02 \%$ sodium azide, sectioned, and stored frozen at $-80^{\circ} \mathrm{C}$. Rat hippocampal and cortical cells were dissected from Sprague Dawley fetuses at $18 \mathrm{~d}$ of gestation, as described (Banker and Cowan, 1977; Dichter, 1978). Cells (0.02\% glia, 99.98\% neurons) (Bown et al., 2003) were dispersed and cultured following the procedure detailed previously (Brewer et al., 1993). Briefly, dispersed cells were resuspended in Neurobasal media (Invitrogen, Burlington, Ontario) containing B27 supplements (Invitrogen), $0.5 \mathrm{~mm}$ L-glutamine, $1 \%$ penicillin/streptomycin, and $25 \mu \mathrm{M}$ glutamate. Cells were plated on poly-D-lysine (molecular weight 30,000-70,000)-coated vessels and maintained at $37^{\circ} \mathrm{C}, 5 \% \mathrm{CO}_{2}$ for $13 \mathrm{~d}$. Cells were fixed in $4 \%$ paraformaldehyde in PBS for $1 \mathrm{hr}$ at $37^{\circ} \mathrm{C}$. Brain sections and cells were blocked and permeablized in $1 \%$ BSA, $5 \%$ goat serum, $0.3 \%$ Triton $\mathrm{X}-100$, and incubated overnight with 1:50 rabbit anti-NUDR primary antibody in combination with 1:500 guinea pig anti-5-HT1A (Chemicon) or guinea pig anti-5-HT (A. A. Verhofstad, Nijmegen, Sweden) followed by secondary goat Texas Red-coupled anti-rabbit (Calbiochem, San Diego, CA) antibody (1:400) and goat anti-guinea pig Alexa Fluor 488 (Molecular Probes) antibody (1:400) in 1\% BSA, 5\% goat serum, $0.3 \%$ Triton X-100 for $30 \mathrm{~min}$ at room temperature. Primary cortical and hippocampal cells were immunostained as above for the major microtubule-associated protein (MAP2) and the $\beta 3$ tubulin early neuronal marker (TuJ1) using 1:250 mouse anti-MAP2 (Sigma) and 1:100 anti-TuJ1 (D. Brown, University of Ottawa) followed by 1:400 secondary goat anti-mouse Cy3 (Jackson ImmunoResearch Laboratories, West Grove, PA). Immunofluorescence was visualized under a Zeiss Axioscop 2 microscope, and images were captured using a Sony Hyper Had color camera and Northern Eclipse software (Emphix imaging).

\section{Western blot analysis}

Rat brain tissues were homogenized in buffer A (10 mM HEPES, pH 7.9, $1.5 \mathrm{~mm} \mathrm{MgCl}_{2}, 10 \mathrm{~mm} \mathrm{KCl}, 0.5 \mathrm{~mm}$ DTT, and 0.1\% NP-40). Nuclear extracts were obtained as described (Ou et al., 2000). Twenty micrograms of nuclear proteins from RN46A, rat midbrain, cortex, and hippocampus were separated by SDS-PAGE on a $12 \%$ gel. After transfer to nitrocellulose membrane and blockage with TBS containing 5\% dry milk and $0.01 \%$ Tween 20 , immunoreactive proteins were detected with rabbit anti-Hes 5 or anti-NUDR antibodies at a dilution of 1:1000 followed by a 1:2000 dilution of the secondary horseradish peroxidase (HRP)-linked anti-rabbit antibody. To assess for 5-HT1A and NUDR expression in RN46A or NUDR overexpressing clones, whole-cell extracts were prepared by sonication in NP-40 basic solution (1\% NP-40, $50 \mathrm{~mm}$ Tris, $\mathrm{pH}$ $7.4,150 \mathrm{~mm} \mathrm{NaCl}$ ) containing a mixture of protease inhibitors (Roche Diagnostics, Mannheim, Germany). Eighty micrograms of total protein were loaded on $12 \%$ SDS-PAGE gels, and immunoreactivity was detected using anti-NUDR and anti-5-HT1A antibodies at a dilution of 1:1000 followed by a 1:2000 dilution of the secondary HRP-conjugated antirabbit and anti-guinea pig antibodies, respectively. Anti- $\beta$-actin antibody (Sigma) was used at a 1:10,000 dilution followed by HRPconjugated anti-mouse secondary antibody at a dilution of 1:2000.

\section{Plasmid constructs and transfections}

The luciferase plasmid 5-HT1A(C) was obtained by insertion of a KpnI$B s s H I$ fragment of the human 5-HT1A promoter (cloned from human genomic library) into pGL3-Basic (Promega) digested with KpnI and MluI. The 5-HT1A(G) construct contained the C(-1019)G mutation that was generated by unique site elimination mutagenesis (Amersham Biosciences) of 5-HT1A(C). Plasmids 26bp-C(TK) and 26bp-G(TK) were generated by annealing complementary oligonucleotides of the $26 \mathrm{bp}$ polymorphic element flanked by SacI and NheI sites and subcloning into SacI-NheI-cut pGL3-Basic containing the herpes simplex virus-thymidine kinase promoter between SalI and XhoI sites. Appropriate oligonucleotides of the 26 bp element flanked with CC and GG 3' overhangs were annealed, concatenated in six copies using T4 DNA ligase, blunted with Klenow, and subcloned into SmaI-cut pGL3-Promoter to generate 26bp$\mathrm{C}(6)$ and $26 \mathrm{bp}-\mathrm{G}(6)$. All constructs were verified by DNA sequence analysis. Human embryonic kidney (HEK) 293 or RN46A cells were maintained and transfected as described previously (Storring et al., 1999; Ou et al., 2000). NUDR and Hes5 expression plasmids were subcloned by digestion of pACT2 clones 76D (lacking the first 16 amino acids) or $18 \mathrm{C}$ (full length) with BglII and subsequent ligation with BamHI-digested pcDNA3 (Invitrogen). Full-length NUDR was obtained by PCR amplification using the human brain Marathon-Ready cDNA kit (Clontech). The PCR product was subcloned in pGEM-T Easy vector (Promega) before subcloning in the EcoR1 site of pcDNA1 (Invitrogen).

\section{Generation and analysis of stable clones}

RN46A cells were cotransfected with $5 \mu \mathrm{g}$ of NUDR-pcDNA3 expression plasmid and $0.25 \mu \mathrm{g}$ of PGK-puro (gift of M. McBurney, University of Ottawa) using Pfx-7 lipid mixture (Invitrogen). Cells were selected for puromycin resistance $(3 \mu \mathrm{g} / \mathrm{ml})$ for 3-4 weeks, and antibiotic-resistant clones were picked, expanded, and tested for the expression of NUDR using Northern (data not shown) and Western blot analysis. For ligandbinding studies, cell membranes from parental or NUDR-transfected RN46A cells were prepared as described (Albert et al., 1990) and stored at $-80^{\circ} \mathrm{C}$. Aliquots of thawed and dissociated membrane preparations (100 $\mu \mathrm{g}$ per tube) were added to triplicate tubes containing $200 \mu \mathrm{l}$ TME (75 mu Tris, pH 7.4, $12.5 \mathrm{~mm} \mathrm{MgCl}, 1 \mathrm{~mm}$ EDTA) and $10 \mathrm{~nm}\left[{ }^{3} \mathrm{H}\right]-8-\mathrm{OH}-$ DPAT (Amersham Biosciences) without or with $10 \mu \mathrm{M}$ 5-HT to determine total versus nonspecific binding at room temperature $(30 \mathrm{~min})$. Reactions were terminated by filtration through GF/C (Whatman) filters and washed with $3 \mathrm{ml}$ of cold buffer ( $50 \mathrm{~mm}$ Tris- $\mathrm{HCl}, \mathrm{pH} 7.4$ ), and $5 \mathrm{ml}$ of scintillation fluid was added to filters to quantify radioactivity by liquid scintillation counting. For semiquantitative RT-PCR, total RNA from rat RN46A cells was isolated using Trizol reagent (Invitrogen), and genomic DNA was removed by DNase treatment (confirmed by PCR analysis). Reverse transcription-PCR was done using SuperScript onestep reverse transcriptase-PCR (RT-PCR) with Platinum Taq (Invitrogen), using specific primers for rat 5-HT1A and GAPDH: 5-HT1A (360 bp), 5'-GCCATCGCGCTAGACAGGTA-3' (sense) and 5'-GCGGTGCCGACGAAGT-3' (antisense); rat GAPDH (120 bp), 5'-CATGGCCTTCCGTGTTCCTACCC-3' (sense) and 5'-CCTCGGCCGCCTGCTTCA-3' (antisense). Amplified cDNA fragments were run on a $1.2 \%$ agarose gel containing ethidium bromide and quantified using UN-SCAN-IT software version 4.3 (Silk Scientific Corporation). All values are normalized to GAPDH.

\section{Results}

\section{Association of the $\mathrm{C}(-1019) \mathrm{G}$ polymorphism with major depression and suicide}

Genomic DNA extracted from blood samples of 129 depressed patients and 134 age- and ethnicity-matched controls was amplified by PCR using primers directed at the repressor region of the 5-HT1A receptor gene and sequenced. The C (-1019) G polymorphism was the only alteration detected within this region (Fig. 1). There was a twofold increase in the frequency of the homozygous $\mathrm{G} / \mathrm{G}$ allele in severely depressed patients versus controls (Table $1)$. The genotype $(p=0.0017)$ and allele frequencies $(p=$ 0.0006 ) were significantly different between patients with major 


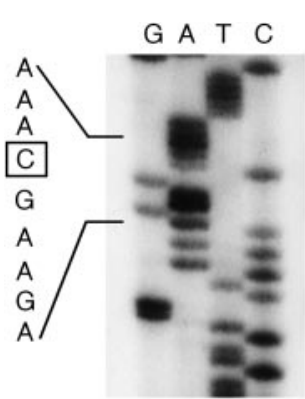

1

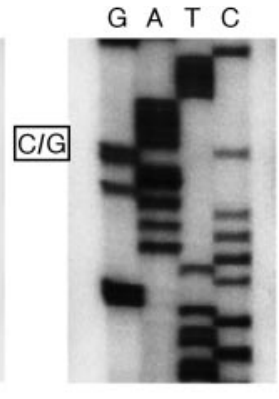

2

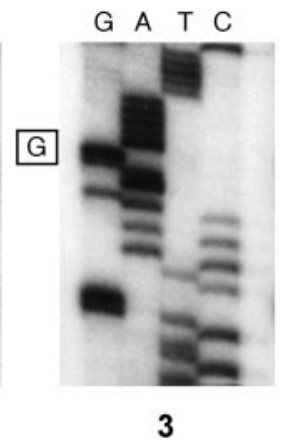

3
Figure 1. A C(-1019)G polymorphism of the human 5-HT1A receptor promoter. A 716 bp fragment in the repressor region of the human 5-HT1A promoter was amplified by PCR and sequenced. Shown is a partial DNA sequence from PCR products of three different depressed patients that revealed the homozygous $((-1019)$ sequence $(1)$, the heterozygous sequence with both C and $\mathrm{G}$ at the (-1019) site (2), and the homozygous $\mathrm{G}(-1019)$ sequence (3).

Table 1. Distribution of the 5-HT1A receptor G(-1019) gene polymorphism in depressed patients and control subjects from the Ontario cohort

\begin{tabular}{llllllll}
\hline & & \multicolumn{3}{l}{ Genotypes } & & \multicolumn{2}{l}{ Alleles } \\
Subjects & $\mathrm{N}$ & $\mathrm{C} / \mathrm{C}$ & $\mathrm{C} / \mathrm{G}$ & $\mathrm{G} / \mathrm{G}$ & & $\mathrm{C}$ & $\mathrm{G}$ \\
\hline Controls & 134 & 50 & 68 & 16 & & 168 & 100 \\
Major depression & 129 & 30 & 63 & 36 & & 123 & 135
\end{tabular}

Control subjects versus depressed patients: genotype, $\chi^{2}=12.79, \mathrm{df}=2, p=0.0017$; allele, $p=0.0006$ Presence of any C allele versus absence of any C allele, $p=0.0018$. Presence of any $\mathrm{G}$ allele versus absence of any $\mathrm{G}$ allele, $p=0.0158$.

Table 2. Distribution of the 5-HT1A receptor G(-1019) gene polymorphism in suicide completers and normal controls from the Quebec cohort

\begin{tabular}{llllllll}
\hline & & \multicolumn{3}{l}{ Genotypes } & & \multicolumn{2}{l}{ Alleles } \\
\cline { 3 - 5 } \cline { 7 - 8 } Subjects & $\mathrm{N}$ & $\mathrm{C} / \mathrm{C}$ & $\mathrm{C} / \mathrm{G}$ & $\mathrm{G} / \mathrm{G}$ & & $\mathrm{C}$ & $\mathrm{G}$ \\
\hline Controls & 116 & 85 & 26 & 5 & & 196 & 36 \\
Suicide & 102 & 55 & 30 & 17 & & 140 & 64 \\
\hline
\end{tabular}

Control subjects versus suicide cases: genotype, $\chi^{2}=12.41, \mathrm{df}=2, p=0.002 ;$ allele, $p=0.00008$. Presence of any $C$ allele versus absence of any $C$ allele, $p=0.003$. Presence of any $\mathrm{G}$ allele versus absence of any $\mathrm{G}$ allele, $p=$ 0.0045 .

depression and control subjects, indicating an association between the $\mathrm{C}(-1019) \mathrm{G}$ polymorphism and major depression. To assess its possible association with suicide, genotype and allele frequencies of the $\mathrm{C}(-1019) \mathrm{G}$ polymorphism were investigated in an independent sample comprising 102 suicide completers and 116 normal controls of similar ethnic background (FrenchCanadian) (Table 2). The suicide cases carried the G(-1019) variant more frequently than controls (genotypes: $p=0.002$; alleles: $p=0.00008$ ). Importantly, the homozygous $\mathrm{G} / \mathrm{G}$ genotype was four times more frequent among suicide completers. Thus the G(-1019) allele was associated with completed suicide and with major depression in two separate populations.

\section{Specific protein-DNA interaction at an imperfect palindrome containing $\mathrm{C}(-1019)$}

We addressed whether the $\mathrm{C}(-1019) \mathrm{G}$ polymorphism of the 5-HT1A receptor gene might affect 5-HT1A receptor expression. The $\mathrm{C}(-1019)$ polymorphism (italic type) is incorporated within an imperfect palindrome (bold type), 5'-AACGAAGAC ACACTCG GTCTTCTT- ${ }^{\prime}$, and we first addressed whether proteins bind to this DNA sequence. EMSA was done using a $26 \mathrm{bp}$ probe incorporating the palindrome in the absence or presence of nuclear extract from RN46A cells, a serotonergic raphe neuronal cell line that expresses 5-HT1A receptors (Eaton et al., 1995; Stor-
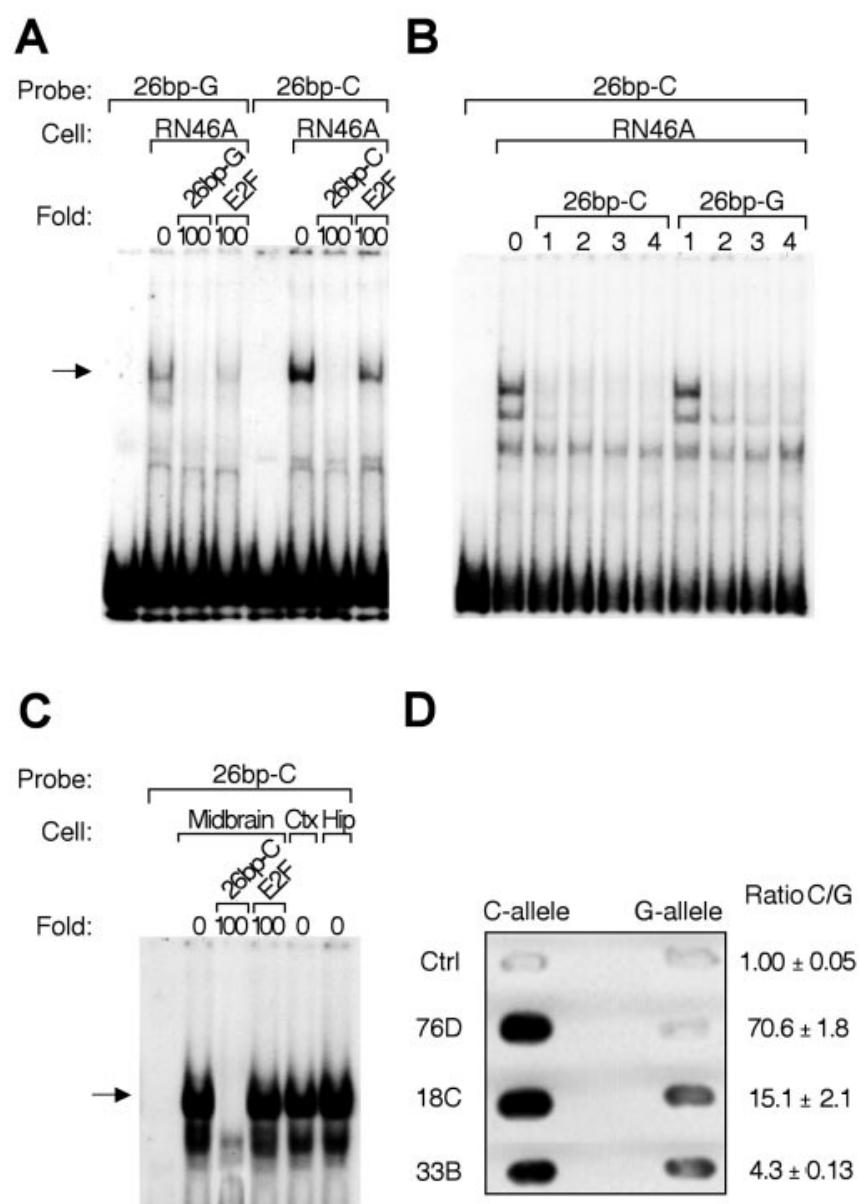

Figure 2. Allele-specific association of a nuclear protein complex with the C(-1019) palindrome of the 5-HT1A receptor gene. EMSA was done using a $26 \mathrm{bp}$ probe that includes the C(-1019)G polymorphism of the human 5-HT1A receptor gene associated with depression. Labeled 26 bp oligonucleotide probes were present in samples as the $C(-1019)$ or the $\mathrm{G}(-1019)$ allele as indicated. Unlabeled 26 bp oligonucleotides (26bp-C or $26 \mathrm{bp}-\mathrm{G}$ ) or unrelated E2F oligonucleotides (E2F) were added at 100-fold or 1-, 2-, 3-, or 4-fold molar concentration to the incubation as indicated. $A$, Using RN46A nuclear extracts, a single major specific complex was observed (arrowhead) that showed preferential binding to the 26bp-C oligonucleotide. B, Decreased competition was observed with the $26 \mathrm{bp}-\mathrm{G}$ oligonucleotide, which required a twofold molar excess to start competing with the $26 \mathrm{bp}-\mathrm{C}$ probe for RN46A nuclear extracts. C, Nuclear extracts from rat brain tissues, including raphe-midbrain, cortex (Ctx), and hippocampus (Hip), showed specific binding to the labeled $26 \mathrm{bp}-C$ oligonucleotide (arrowhead). D, Yeast onehybrid cloning of binding proteins specific for the $C(-1019)$ palindrome allele. Six copies of the $\mathrm{C}(-1019)$ or $\mathrm{G}(-1019)$ alleles of the 26 bp element of the 5 -HT1A receptor gene were integrated in the yeast genome $5^{\prime}$ to the LacZ gene. The two yeast strains generated were nontransformed (Ctrl) or transformed with plasmid DNA from the indicated cDNA clones (76D, 18C, or 33B). Trans-activation was measured by $\beta$-galactosidase activity in a plate assay (left) and by quantitative spectrophotometry to calculate the activity ratio of $C / G$ (right), expressed as mean \pm SD $(n=2)$.

ring et al., 1999). A single major protein-DNA complex was detected using the $\mathrm{C}(-1019)$ allele (26bp-C), which was competed by unlabeled 26 bp oligonucleotides but not by unrelated E2F oligonucleotides, indicating a specific interaction (Fig. $2 A$ ). Importantly, the $G(-1019)$ allele displayed considerably reduced protein-DNA complex formation with an approximate twofold decrease in affinity (Fig. $2 \mathrm{~B}$ ). A specific protein-DNA complex of the same mobility as in RN46A raphe cells was also demonstrated 
in vivo, using extracts from adult rat brain regions including the midbrain, which contains the raphe nuclei (Fig. 2C).

To identify specific trans-acting proteins, six copies of the 26 bp polymorphic element were placed upstream of various selectable markers and $2 \times 10^{6}$ independent clones of a human brain cDNA library were screened by the yeast onehybrid approach. Two clones (76D, 18C) trans-activated the $\mathrm{C}(-1019)$ allele robustly, and one (33B) weakly transactivated (Fig. 2D). The C(-1019)G mutation reduced trans-activation in a clonespecific manner. Clones 76D (70-fold reduction in activity to detection limit) and $18 \mathrm{C}$ (15-fold reduction) were sensitive to the $\mathrm{C}(-1019) \mathrm{G}$ change, whereas clone $33 \mathrm{~B}$ was relatively insensitive and was not examined further.

Clone 76D was identical to human NUDR/suppressin/DEAF-1 (Gross and McGinnis, 1996; Huggenvik et al., 1998; LeBoeuf et al., 1998; Sugihara et al., 1998), a homolog of the Drosophila helix-loophelix transcription factor, DEAF-1. NUDR is a novel transcription factor containing a SAND (Sp100, Aire, Nuc P41/75, DEAF-1) domain that binds to the minimal consensus TTCG site (Huggenvik et al., 1998; Bottomley et al., 2001). The imperfect palindrome of the 5-HT1A receptor contains an inverted TTCG, and the $\mathrm{C}-\mathrm{G}$ change destroys the NUDR element. Clone 18C had 91\% nucleotide homology with mouse Hes5. This helix-loop-helix transcription factor binds to a consensus $\mathrm{N}$ box (CACNAG) (Akazawa et al., 1992), and a similar sequence (CACNCG) is located near the $\mathrm{C}-\mathrm{G}$ polymorphism. Both NUDR and Hes5 function as transcriptional repressors (Akazawa et al., 1992; Michelson et al., 1999), and their ability to regulate the 5-HT1A receptor gene was examined in 5-HT1A receptor-positive ( $\mathrm{RN} 46 \mathrm{~A})$ or receptor-negative (HEK 293) cells.

\section{Repressor activity of the $\mathrm{C}(-1019)$ palindrome sequence}

The repressor activity of NUDR or Hes 5 at the human 5-HT1A promoter (Parks and Shenk, 1996) was examined by cotransfecting expression plasmids with a luciferase reporter construct containing $1.128 \mathrm{~kb}$ of promoter sequence comparing the $\mathrm{C}(-$ 1019) or G(-1019) alleles denoted 5-HT1A(C) and 5-HT1A(G), respectively (Fig. $3 A, B$ ). In vector-transfected cells, the basal luciferase activity of the two alleles of this promoter construct was not significantly different; hence the role of the polymorphism in basal 5-HT1A transcription was unclear. The -1128-luc 5-HT1A construct contains multiple interacting elements that could mask the effect of the $\mathrm{C}$ to $\mathrm{G}$ transition on basal transcription. Cotransfection of NUDR or Hes5 inhibited the transcriptional activity of the 5-HT1A(C) construct $(p<0.0001)$ in HEK
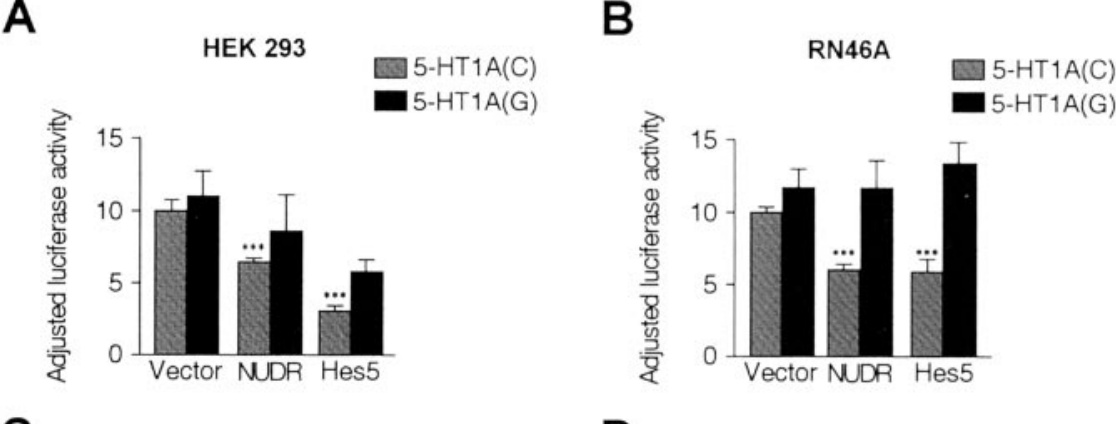

HEK 293

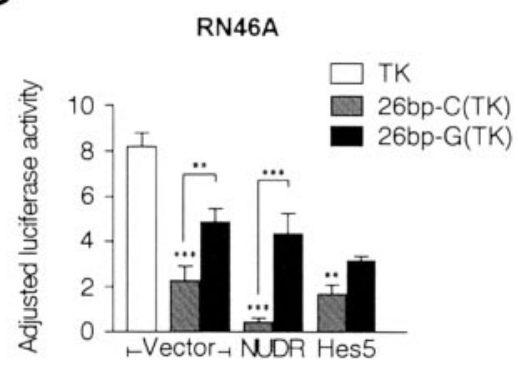

E

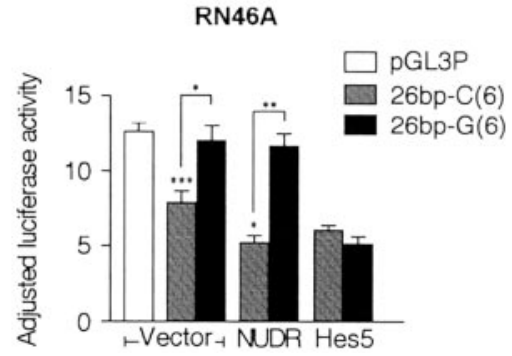

Figure 3. Trans-repression at the palindrome of the 5-HT1A receptor gene by NUDR and Hes5: differential sensitivity to the $C(-1019) G$ polymorphism. Human 5-HT1A receptor-negative HEK $293(A, C)$ or receptor-positive raphe RN46A cells $(B, D, E)$ were cotransfected with the indicated luciferase reporter constructs and vector (pcDNA3), NUDR, or Hes5 expression plasmids, as indicated. Data are expressed as adjusted luciferase activity corrected for transfection efficiency by determining the ratio of luciferase activity/ $\beta$-galactosidase activity as described (Ou et al., 2000) and are presented as mean \pm SD of triplicate samples from experiments that were repeated at least twice. Statistical significance compared with vector control (for NUDR and Hes5) or by unpaired $t$ test with two-tailed $p$ values: ${ }^{*} p<0.05,{ }^{* *} p<0.005,{ }^{* * *} p<0.0005$. A, B, Repression of the human 5-HT1A promoter ( -1128 bp to the initiation ATG) by NUDR and Hes5 in HEK $293(A)$ and RN46A cells $(B)$. The C(-1019) or G(-1019) allele of the -1128 bp 5-HT1A promoter-luciferase reporter construct [5-HT1A(C) and 5-HT1A(G), respectively] was cotransfected with vector, NUDR, or Hes5. Compared with vector, NUDR and Hes5 repressed 5-HT1A(C) but lacked significant activity at the G(-1019) allele, 5-HT1A(G). C, D, The 26 bp 5-HT1A palindrome mediates repression of TK promoter by NUDR and Hes5. Reporter constructs containing TK promoter alone (TK, open bars) or the $26 \mathrm{bp} 5$-HT1A palindrome $C$ or $G$ allele placed upstream $\left(5^{\prime}\right)$ of TK [26bp-C(TK) or 26bp-G(TK), respectively] were cotransfected with vector, NUDR, or Hes 5 plasmids in HEK 293 ( C) or RN46A cells (D). NUDR and Hes5 mediated repression via the 26 bp DNA elements, but only NUDR was entirely specific for the $C$ allele. $E$, Repression of SV40 promoter (pGL3P, open bar) at a hexamer of 26 bp elements in RN46A cells. Six copies of the 26 bp element [26bp-C(6) or $26 \mathrm{bp}-\mathrm{G}(6)]$ were placed upstream of the SV40 promoter in the PGL3P plasmid. The $\mathrm{C}-\mathrm{G}$ change blocked basal repression and repression augmented by NUDR but not Hes5.

293 and RN46A cells. By contrast, NUDR did not repress the 5-HT1A $(G)$ construct, whereas Hes5 partially inhibited transcription of the G(-1019) allele in HEK 293 cells but failed to repress the 5-HT1A promoter in RN46A cells. Thus, repression of the 5-HT1A promoter by NUDR and Hes5 was specific for the C(-1019) allele, although Hes5 had weak activity at the G(-1019) site.

To address more directly whether the 26 bp 5-HT1A palindrome sequence functions as a repressor element, it was placed adjacent to heterologous promoters, TK and SV40. Because the -1128-luc 5-HT1A promoter construct contains multiple DNA elements, repression by NUDR or Hes 5 could be mediated by 
indirect mechanisms such as antagonism of enhancer proteins that act at other elements. The repressor activity of NUDR and Hes 5 at the C- or G-allele [26bp-C(TK) or 26bp-G(TK)] of the 26 bp 5-HT1A palindrome sequence placed 5' to the TK promoter was examined in HEK 293 and RN46A cells (Fig. 3C,D). In vector (pcDNA3) transfected cells, the basal activity 26bp-C(TK) construct was reduced to 45 and $25 \%$ of the control (TK) reporter activity in HEK 293 and RN46A cells, respectively, suggesting the presence of endogenous repressors in these cells. Repression of basal transcription activity of the TK promoter was significantly attenuated for the 26bp-G(TK) construct in both cell lines, although its activity was significantly less than for TK promoter alone. This indicates that the $26 \mathrm{bp} 5$-HT1A palindrome confers basal repression that is sensitive but not completely inhibited by the $\mathrm{C}-\mathrm{G}$ polymorphism. Compared with vector, cotransfection with NUDR further repressed TK promoter activity of the 26bpC(TK) construct $(p<0.001)$ by $35 \%$ in HEK 293 cells and $80 \%$ in RN46A (Fig. 3C,D). Transfection with Hes5 significantly reduced the activity of $26 \mathrm{bp}-\mathrm{C}(\mathrm{TK})$ by $60 \%$ in HEK 293 and by only $20 \%$ in RN46A cells. Importantly, in both cell lines NUDR failed to repress the $26 \mathrm{bp}-\mathrm{G}(\mathrm{TK})$ construct compared with vector control, whereas Hes5-induced repression was not significantly different for C- or G-alleles in either cell line. Thus, both NUDR and Hes5 mediated repression via DNA elements present on the 5-HT1A palindrome sequence, but only NUDR was entirely specific for the $\mathrm{C}$ allele.

To further validate the repressor activity of the 26 bp 5-HT1A palindrome at different heterologous promoters and to provide a more sensitive assay, six copies of the palindrome were placed $5^{\prime}$ to the viral SV40 promoter [C-allele, 26bp-C(6); G-allele, 26bp$\mathrm{G}(6)]$. To stringently address the specificity of NUDR or Hes5 at the C- or G-allele of the palindrome, RN46A raphe cells were cotransfected with these SV40 reporter constructs and vector, NUDR, or Hes5 expression constructs (Fig. 3E). In vectortransfected cells, basal transcriptional activity of the 26bp-C(6) construct was reduced by $40 \%$ compared with the SV 40 promoter control (pGL3P), whereas the G-allele [26bp-G(6)] lacked basal repressor activity (Fig. 3E). Both NUDR and Hes5 repressed transcription of $26 \mathrm{bp}-\mathrm{C}(6)$ by an additional $25-35 \%$, but NUDR failed to repress the 26bp-G(6) construct, whereas Hes5 repressed the $\mathrm{G}$-allele to the same extent as the $\mathrm{C}$ allele. The ability of Hes 5 to repress at the $\mathrm{G}$ allele is consistent with the detectable activity of Hes5 at the G-allele in the yeast one-hybrid assay (Fig. $2 D)$. Taken together, these results indicate that the $\mathrm{C}(-1019)$ allele of the palindrome sequence mediated repression of the 5-HT1A or heterologous (SV40 or TK) promoters, whereas the G allele was inactive or weakly active. Moreover, both NUDR and Hes5 function as repressors at the $26 \mathrm{bp}$ palindrome of the 5-HT1A receptor, but NUDR is exclusively selective for the $\mathrm{C}$ allele.

\section{Detection of NUDR in a protein-DNA complex from raphe nuclear extracts}

Because NUDR specifically repressed the C(-1019) allele of the 5-HT1A promoter, we assessed the importance of recombinant or endogenous NUDR in raphe RN46A cells or raphe-midbrain nuclear extracts to recognize the 26 bp palindrome $\mathrm{C}(-1019)$ allele (26bp-C) using EMSA and DNase I protection analysis (Fig. 4). Incubation of in vitro-transcribed and translated recombinant NUDR bound to labeled $26 \mathrm{bp}-\mathrm{C}$, and this was competed with 100 -fold unlabeled 26bp-C but not the unrelated E2F DNA element (Fig. 4A). By contrast, binding of recombinant Hes5 to 26bp-C was detectable but weak (data not shown). Second, nu-
A

B

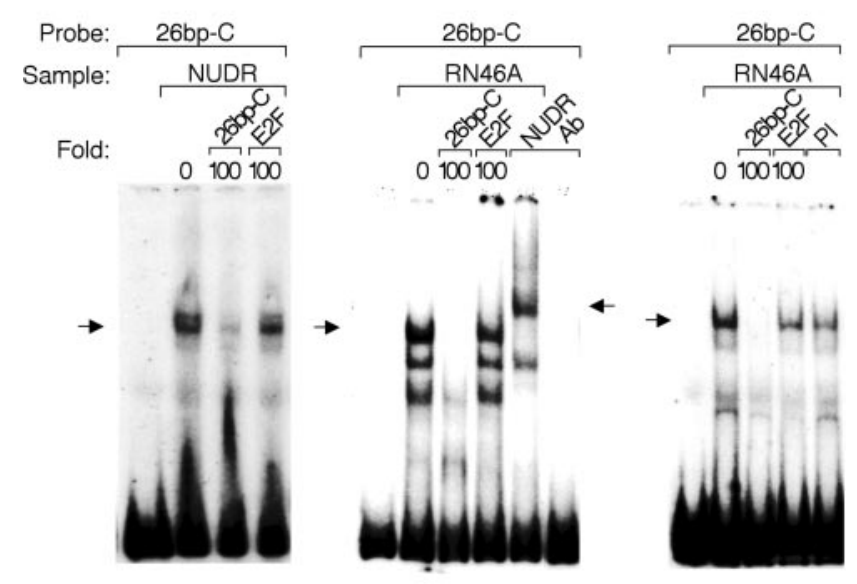

D

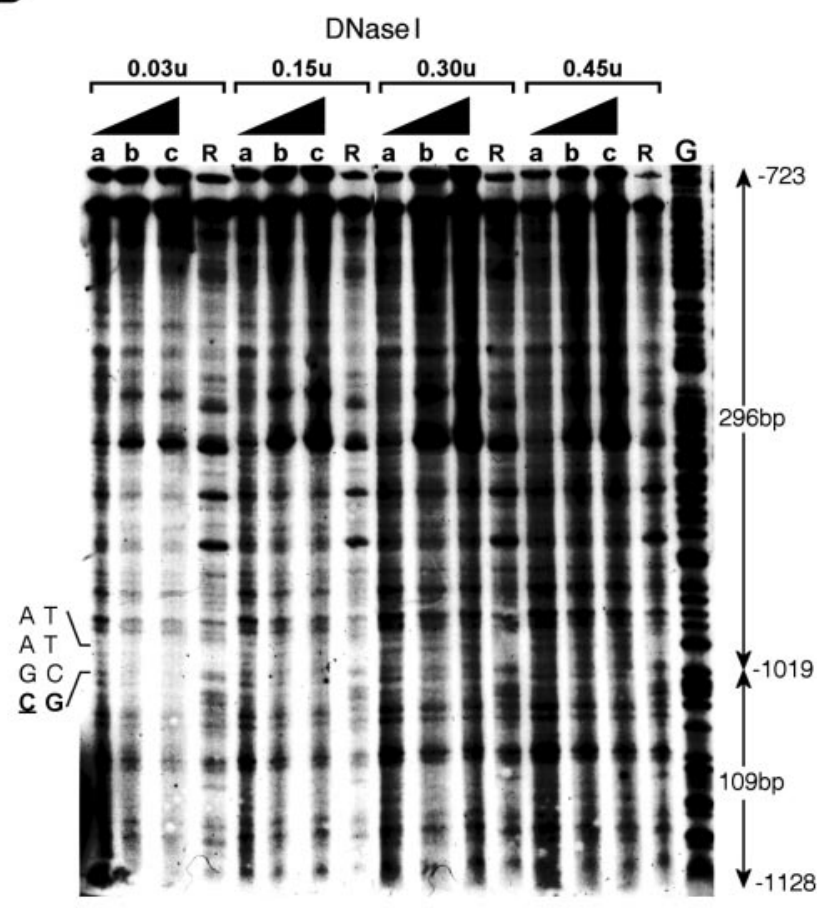

Figure 4. Presence of NUDR bound to the C(-1019) allele in RN46A nuclear extracts. EMSA was done with the $26 \mathrm{bp}-C$ probe using recombinant NUDR or RN46A nuclear extracts as indicated. Unlabeled 26 bp oligonucleotides (26bp-C) or unrelated E2F oligonucleotides (E2F) were added at 100 -fold molar excess to the incubation as indicated. $A$, In vitro-transcribed and-translated recombinant NUDR bound specifically to the $26 \mathrm{bp}-C$ probe. $B$, Binding of endogenous NUDR to the C(-1019) allele in RN46A nuclear extracts. A major specific complex was observed (left arrowhead) that was supershifted (right arrowhead) during incubation with anti-NUDR antibody; anti-NUDR alone did not bind to probe. C, Negative control experiment showing that no supershift of the protein-DNA complex in RN46A cells was induced using rabbit preimmune serum (PI). D, Localization of NUDR binding site within the proximal 5-HT1A promoter region by DNase I protection assay. A 405 bp DNA probe spanning the region between -723 and -1128 was treated with the indicated units of DNase I in the absence (a) or presence of $10 \mu \mathrm{g}$ (b) or $20 \mu \mathrm{g}$ (c) of raphe-midbrain nuclear extracts, or in the presence of recombinant NUDR protein (R). Midbrain extracts and NUDR protected a region centered between -1016 and -1019, corresponding to the TTCG NUDR recognition sequence and the polymorphic site $[\mathbf{C}(-1019) \mathrm{G}]$. The nucleotide position within the 5-HT1A 5' -flanking sequence is marked adjacent to the sequencing reaction $(\mathrm{G})$.

clear extracts from RN46A cells were incubated with labeled 26bp-C, and a major protein-DNA complex was competed using unlabeled 26bp-C but not E2F. NUDR was detected in proteinDNA complexes using a specific antibody generated against 
NUDR (see Materials and Methods) that specifically recognizes NUDR on Western blot (Fig. 5A). Incubation of nuclear extracts with anti-NUDR retarded the migration of the major proteinDNA complex (Fig. $4 B$ ), whereas rabbit preimmune serum did not affect the migration (Fig. $4 C$ ). Incubation of $26 \mathrm{bp}-\mathrm{C}$ with anti-NUDR alone did not result in nonspecific background, indicating that the super-shifted complex contains NUDR. A second faster migrating complex was competed by $26 \mathrm{bp}-\mathrm{C}$ (Fig. $4 B$ ) but was not observed consistently (Fig. $4 C$ ) and was not shifted by NUDR antibody. These results indicate that NUDR is a component of the major protein-DNA complex formed with the 5-HT1A palindrome from raphe RN46A cell nuclear extracts.

To confirm specific binding of NUDR to the 26 bp element in the 5-HT1A promoter, a DNase I protection assay was conducted using an end-labeled DNA fragment spanning the region from -723 to -1128 bp of the 5 -HT1A receptor gene (Fig. $4 D$ ). With increasing concentrations of DNase I, raphe-midbrain extracts protected a progressively restricted region centered between -1016 and $-1019 \mathrm{bp}$, as observed for recombinant NUDR protein $(\mathrm{R})$. This region corresponds to the inverted NUDR binding site (TTCG), the last residue of which is altered by the polymorphism to the inactive TTCC sequence. These data indicate that a nuclear protein complex containing NUDR is present in the midbrain and RN46A cells and recognizes specifically the NUDR DNA element that is present within the palindrome sequence of the 5-HT1A receptor gene. The presence of NUDR in RN46A or adult midbrain extracts and its binding pattern suggests that NUDR is the predominant factor bound to the 5-HT1A palindrome sequence in these tissues.

\section{Downregulation of 5-HT1A receptor protein and binding by NUDR in raphe cells}

To further elucidate the role of NUDR in regulation of the 5-HT1A receptor, we used the anti-NUDR antibody to examine the tissue and cellular expression of NUDR protein (Fig. 5A). By Western blot, NUDR was identified as a single species of $59 \mathrm{kDa}$, corresponding to its predicted molecular mass (Huggenvik et al., 1998). Anti-Hes5 detected a major $28 \mathrm{kDa}$ protein corresponding to Hes5 (Fig. 5B). Both NUDR and Hes5 proteins were expressed in embryonal RN46A cells, but only NUDR was expressed in nuclear extracts from adult brain tissues including midbrainraphe, hippocampus, and cortex. Consistent with this, Hes5 RNA is strongly expressed in embryonic nervous system but is weakly expressed in adult brain (Akazawa et al., 1992). Thus, NUDR functions as a repressor at the 5-HT1A palindrome and is strongly expressed in adult raphe cells.

Having identified the presence of NUDR protein in RN46A cells and midbrain nuclear extracts and its functional importance in regulating 5-HT1A gene transcription (above), we determined whether NUDR regulated the level of functional 5-HT1A receptors in raphe cells. Transcriptional assays indicated that NUDR represses the rat 5-HT1A promoter (data not shown). Thus, rat RN46A cells were stably transfected with NUDR and assayed for 5-HT1A receptor protein and binding activity (Fig. 5C). Three clones transfected with NUDR displayed a four- to fivefold increase in NUDR protein levels compared with nontransfected cells. Expression of 5-HT1A protein was detected by immunoblot and was reduced by $>10$-fold in clones 11 and 15 but less markedly in clone B. The specificity of the 5-HT1A antibody was verified by the absence of signal in receptor-negative rat L6 myoblasts but the presence of the $65 \mathrm{kDa}$ species in L6 cells transfected with a rat 5-HT1A receptor expression plasmid (Fig. 5C, right panel). The $55 \mathrm{kDa}$ species detected in raphe RN46A cells likely represents an additional glycosylated form of the 5-HT1A receptor described previously in rat brain (Verdot et al., 1995). The level of specific 5-HT1A binding sites was also reduced (clone B) or abolished (clones 11 and 15), consistent with the relative protein expression in these clones. Furthermore, the level of 5-HT1A RNA detected by semiquantitative RT-PCR analysis (see Materials and Methods) was reduced by $84 \pm 5,47 \pm 8$, or $50 \pm 12 \%$ in clones $\mathrm{B}, 11$, and 15 compared with RN46A cells (mean \pm SE; $n=$ 3 ). Thus transcriptional repression by NUDR results in a marked decrease in endogenous 5-HT1A RNA, protein, and binding sites in $\mathrm{RN} 46 \mathrm{~A}$ raphe cells.

\section{Colocalization of NUDR and 5-HT1A receptors in vivo}

To provide further evidence supporting a role of NUDR in the regulation of 5-HT1A receptors in vivo, the precise localization of NUDR was determined by immunofluorescence of brain sections and cells (Fig. 5D,E). NUDR protein was most abundant in rat brain structures that express 5-HT1A receptors, including the dorsal raphe nucleus, frontal cortex (data not shown), and pyramidal cells of hippocampal areas CA1 (data not shown), CA2, CA3, and dentate gyrus (Fig. 5D). To address whether NUDR is expressed in the same cells as 5-HT1A receptors, dual immunofluorescence studies were done. NUDR protein was colocalized with 5-HT1A receptor protein in raphe RN46A cells, and in embryonic day 18 (E18) hippocampal and cortical primary cultures (Fig. 5E, panels 1-3). NUDR immunoreactivity observed in raphe, RN46A, hippocampal, and especially cortical cells was localized primarily to nuclear or perinuclear areas, whereas 5-HT1A receptors were also present in the cell body and neuronal processes. In both primary cortical and hippocampal cultures and tissue sections, $>95 \%$ of cells expressing 5 -HT1A receptors also showed NUDR immunoreactivity. The presence of NUDR in the nuclei of these 5-HT1A-positive hippocampal and cortical cells is consistent with its role in regulating 5-HT1A receptor expression.

In tissue sections, NUDR and 5-HT1A receptors were colocalized in the majority of cells of the dorsal raphe nucleus (Fig. $5 E$, panel 4). NUDR and 5-HT1A receptor proteins were also colocalized in the hippocampus and cortex (data not shown). In the raphe nuclei, NUDR was also expressed in 5-HT-containing cells. Because 5-HT1A autoreceptors are present on the majority of serotonin neurons, colocalization of NUDR with these markers supports its role in regulating somatodendritic 5-HT1A autoreceptor expression in raphe neurons in vivo. NUDR was also present in a small proportion of 5-HT1A- or 5-HT-negative cells in the raphe (Fig. $5 E$, arrows) and other brain regions, suggesting additional roles for NUDR.

We determined whether the NUDR-positive cortical and hippocampal cells represent neurons using dual immunofluorescence for both NUDR and neuronal markers MAP2 or TuJ1, an early neuronal marker (Fig. 6A). As expected, MAP2 was localized primarily in the cell body and proximal processes, whereas TuJ1 extended to distal processes of stained cells. Although NUDR was colocalized with both neuronal markers, a small proportion of cells stained for NUDR or a neuronal marker only. Thus most of the NUDR-positive cells in hippocampus and cortical cultures were neurons.

To address concerns of background staining and antibody specificity, several control experiments were done using sections of the raphe nuclei (Fig. 6B). Fixed sections or cells that were incubated with primary or secondary antibody alone, or preincubated with NUDR peptide antigen, displayed only background immunoreactivity. Furthermore, no bleed-through of fluorescence between red and green channels was detected. Taken to- 
A

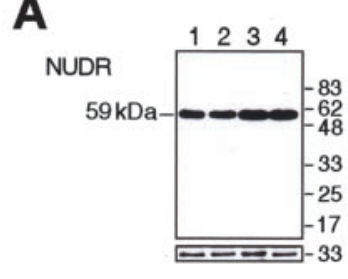

B

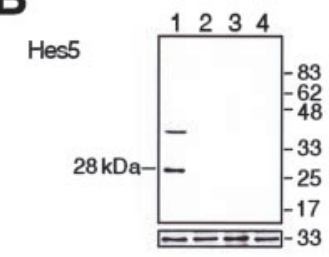

C

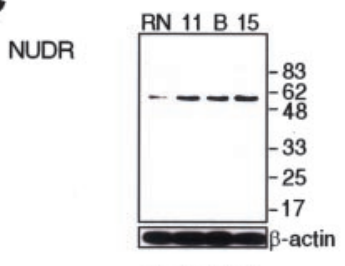

5-HT1A
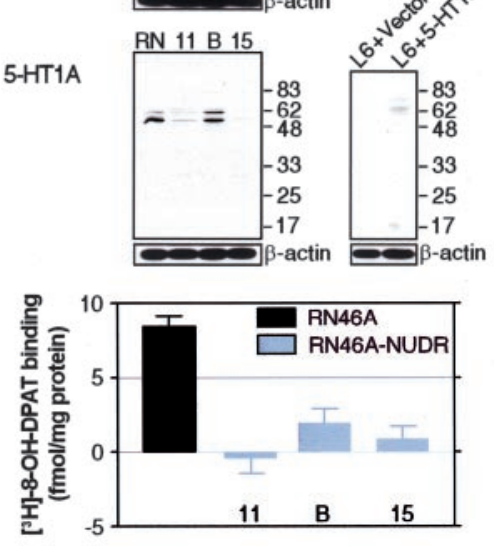

D

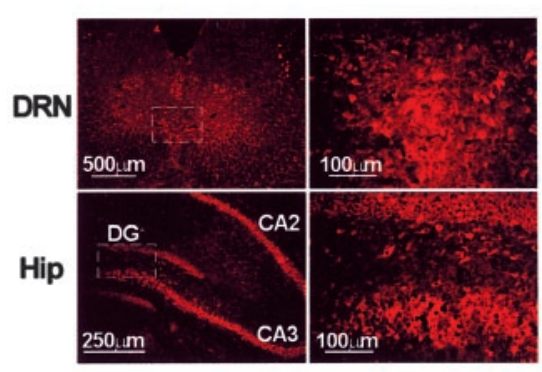

$\mathbf{E}$

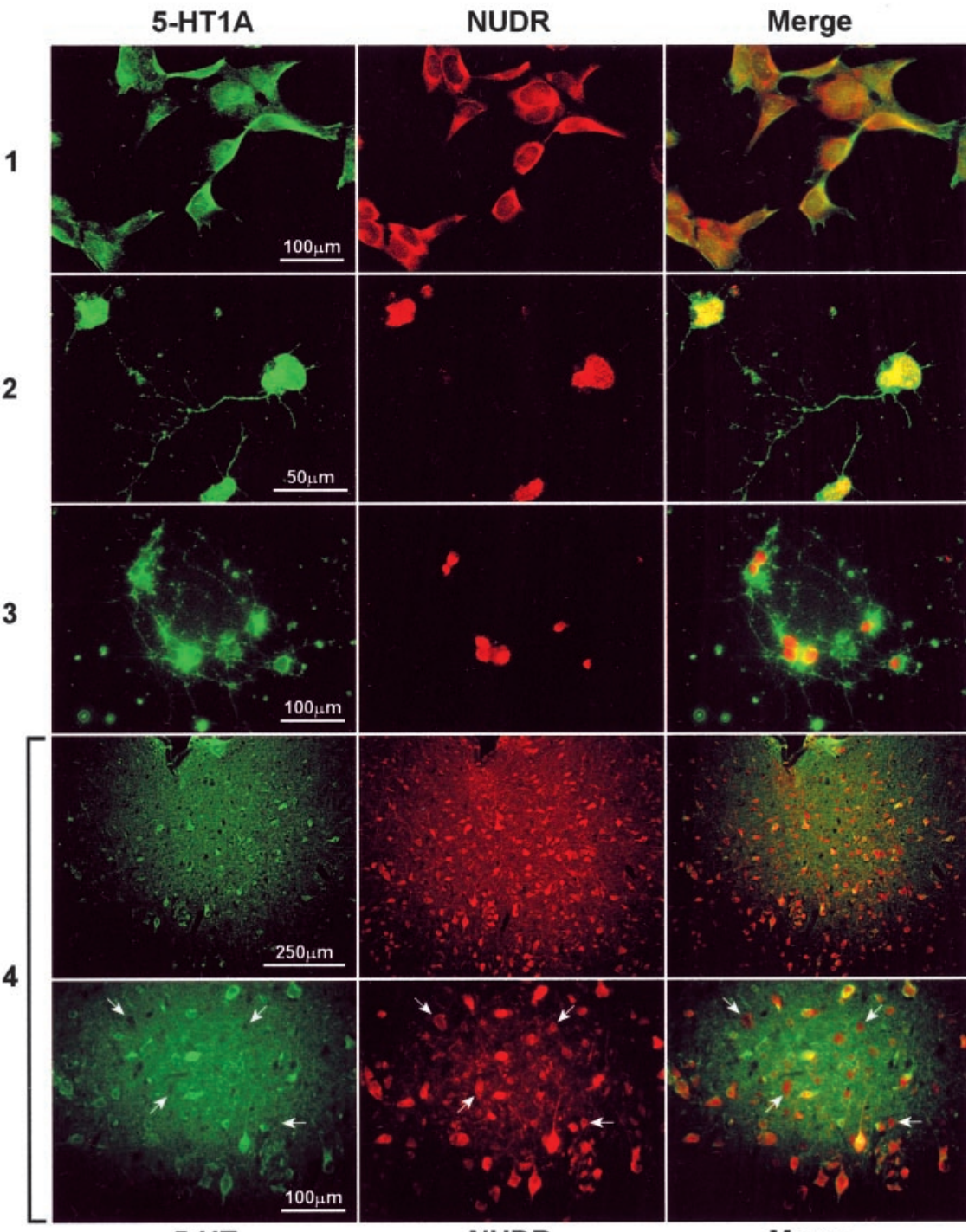

5-HT

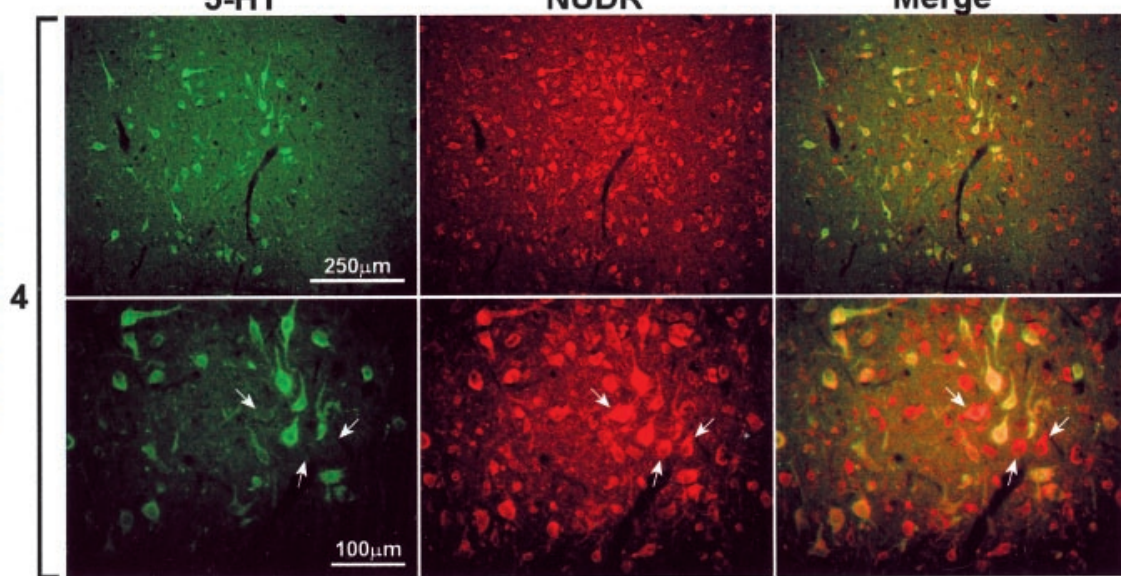

Figure 5. NUDR protein is expressed in 5 -HT1A receptor-positive cells and brain regions and regulates 5 -HT1A protein expression. $A, B$, Western blot analysis of nuclear extracts from RN46A cells (1), adult rat raphe-midbrain (2), cortex (3), and hippocampus (4) using anti-NUDR ( $A$ ) or anti-Hes5 (B) antibodies. A common 33 kDa band on Coomassie-stained gel is shown as a loading control. NUDR was expressed in nuclear extracts from RN46A cells and rat brain tissues, whereas Hes5 expression was restricted to RN46A cells. C, Western blot analysis and [ $\left.{ }^{3} \mathrm{H}\right]-8-\mathrm{OH}-\mathrm{DPAT}$ binding for RN46A cells (RN) stably expressing NUDR (clones 11, B, and 15). Left panels, NUDR reduced 5-HT1A binding and 5-HT1A protein expression. $\beta$-actin immunoreactivity was tested to confirm equal loading. Right panel, Western blot analysis showing specific 5 -HT1A receptor immunoreactivity in myoblast $\mathrm{L} 6$ cells transfected with the rat 5 -HT1A expression vector but not with pcDNA3 vector, as indicated. D, Strong NUDR immunostaining was detected in the dorsal raphe nucleus (DRN) and the CA2, CA3, and dentate gyrus (DG) of the hippocampus (Hip). E, Colocalization (in yellow) of NUDR (in red) and 5-HT1A receptor or 5-HT (in green) in RN46A cells (1), primary cultures of embryonic hippocampal (2), and cortical (3) cells and dorsal raphe nucleus (4). In the dorsal raphe nuclei, some cells (indicated by an arrow) that stained for NUDR displayed weak 5-HT1A receptor or 5-HT staining. 
A

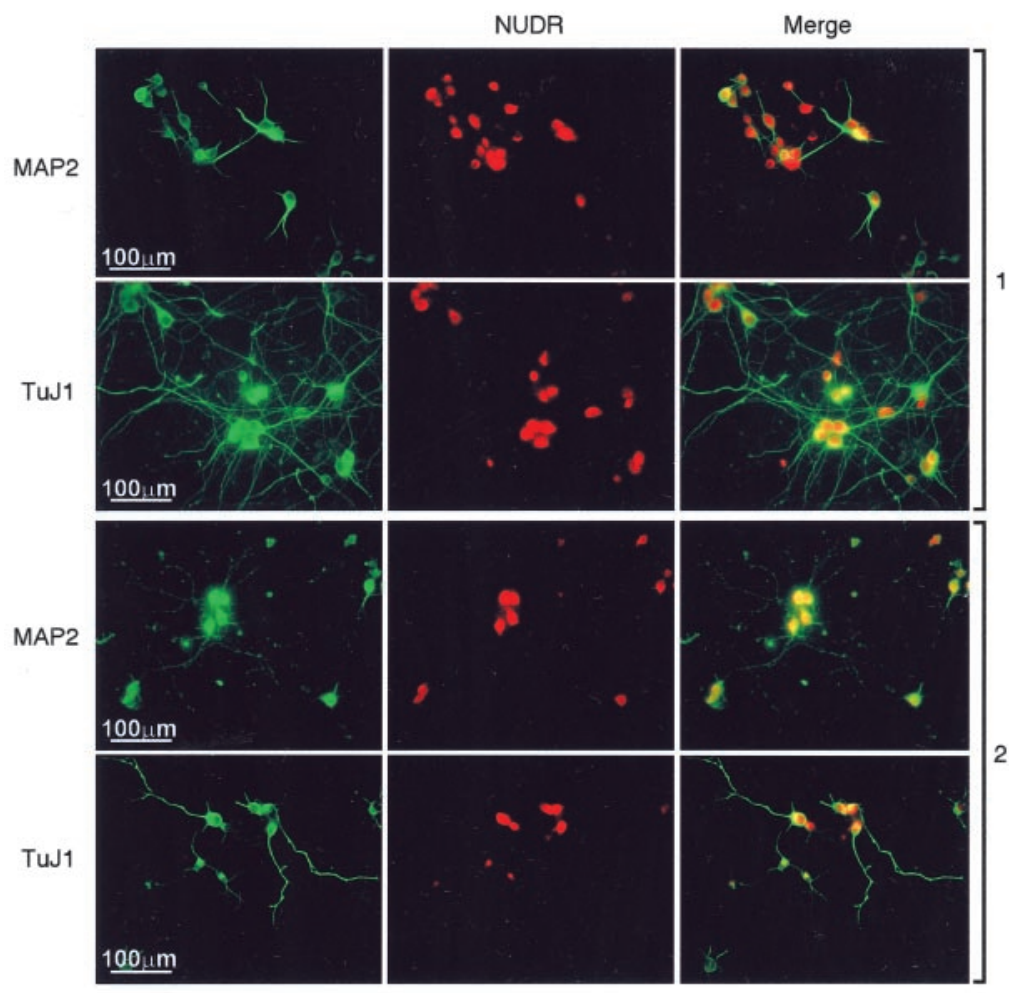

B

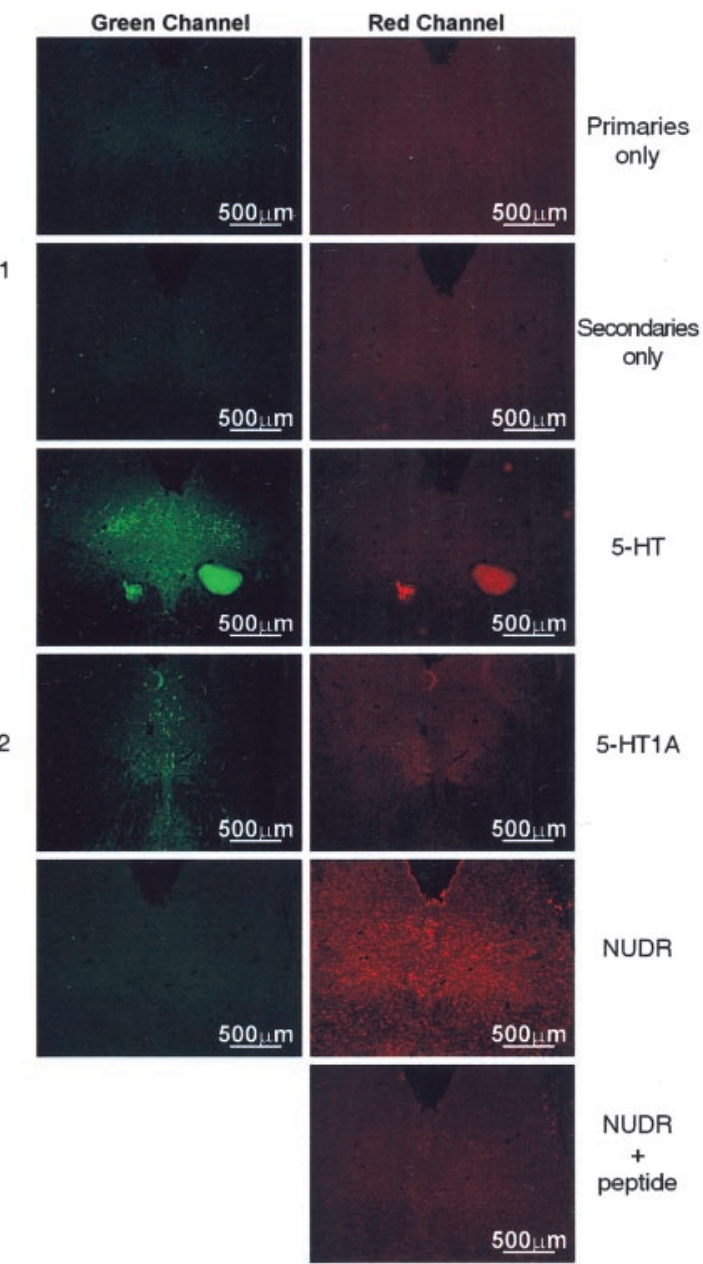

Figure 6. Costaining of NUDR with neuronal markers and specificity of immunohistochemical staining. A, Primary cultures of cortical (1) and hippocampal (2) cells were costained with antibodies to NUDR and neuronal markers MAP2 and TuJ1, demonstrating the presence of NUDR in neurons. B, Specificity of 5-HT, 5-HT1A, and NUDR staining in raphe nuclei. Immunofluorescence was visualized through the green and red channels as indicated using primary 5-HT1A and NUDR antibodies in the absence of secondary antibodies (primaries only). For "secondaries only," these were no primary antibodies in the presence of both secondary antibodies. Specific immunoreactivity was observed through the green but not the red channel using anti-5-HT or anti-5-HT1A antibodies in the presence of both secondary antibodies. NUDR immunoreactivity observed through the red channel was absent in the green channel using both secondary antibodies. NUDR immunofluorescence in the presence of hNUDR $(36-51)$ blocking peptide $(100 \mu \mathrm{g})$ is greatly reduced.

gether, these results indicate that NUDR protein is present in serotonergic neurons and is coexpressed with the 5-HT1A receptor in RN46A cells, raphe nuclei, hippocampus, and other brain regions corresponding to the reported distribution of 5-HT1A receptors (Albert et al., 1990; Chalmers and Watson, 1991; Pompeiano et al., 1992). The pattern of NUDR expression in brain and its coexpression with 5-HT1A receptors supports a role in transcriptional regulation of the 5-HT1A receptor gene in vivo.

\section{Discussion}

These findings constitute the first evidence for a functional genetic association of a 5-HT receptor polymorphism with major depression and suicide. Depressed patients were about twice as likely as controls to have the homozygous G(-1019) genotype, whereas suicide victims were four times as likely to carry the same genotype. Although the results observed in depressed patients are consistent with those observed among suicide completers, they may not be regarded as independent replications. Accordingly, although major depression is one of the most important predictors of suicide, not all depressed patients commit suicide and not all suicide completers have major depression before their death. In this regard, an interesting question is whether the possible effect of the $\mathrm{C}(-1019) \mathrm{G}$ polymorphism on suicide is conditional on depression. The design of this study, however, does not allow us to address this question, and further studies are needed. Additional studies are also needed to validate our findings in independent samples and by means of complementary designs because of the inherent limitations of case-controlled association studies. The $\mathrm{C}(-1019) \mathrm{G}$ polymorphism of the 5-HT1A receptor gene could be one of several serotonin gene regulatory polymorphisms predisposing to depression and to suicide. For example, altered transcriptional regulation of the 5-HT transporter gene is associated with specific alleles implicated in mental illness (Lesch et al., 1996; MacKenzie and Quinn, 1999). Our results are consistent with postulated roles of the 5-HT1A receptor and dysregulation of the serotonergic system in depression and suicide (Blier and de Montigny, 1994; Albert et al., 1996; Artigas et al., 1996; Mann, 1999; Mann et al., 2001) and represent the first evidence associating specific transcription factors (NUDR, Hes5) with major depression and completed suicide. 


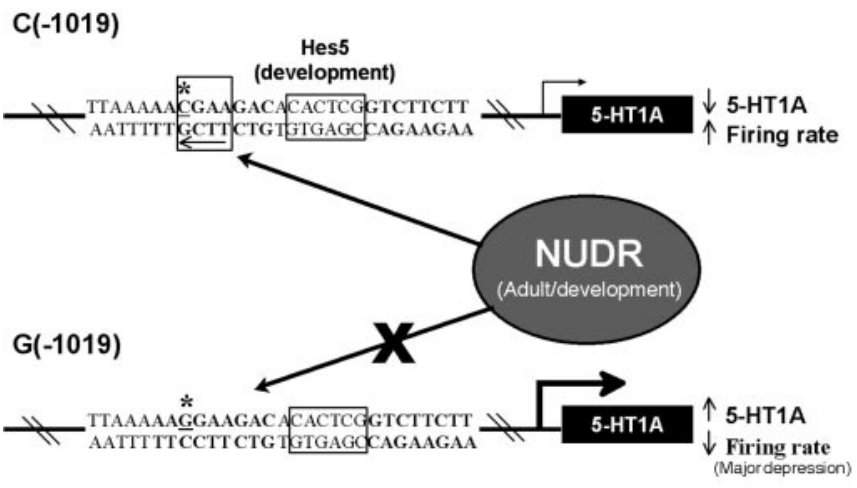

Figure 7. Functional model for derepression at the $5-\mathrm{HT} 1 \mathrm{~A}$ promoter by the $\mathrm{C}(-1019) \mathrm{G}$ polymorphism. The C(-1019)G polymorphism prevents binding of the transcriptional repressor NUDR resulting in enhanced 5-HT1A receptor expression in raphe neurons that may occur in development to adulthood. Increased expression of 5-HT1A somatodendritic autoreceptors would be expected to reduce serotonergic tone, which is associated with major depression. The $C(-1019) \mathrm{G}$ polymorphism also impairs repression by Hes5, which may play a role as a developmental regulator of 5-HT1A gene expression.

These results suggest a molecular mechanism by which the single nucleotide $\mathrm{C}(-1019) \mathrm{G}$ polymorphism may regulate 5-HT1A gene expression in vivo by derepression of the 5-HT1A promoter in presynaptic raphe neurons leading to reduced serotonergic neurotransmission (Fig. 7). The C(-1019)G change dramatically impaired transcriptional repression of the 5-HT1A receptor gene by the identified trans-acting proteins NUDR and Hes5 (Fig. 3). Although both NUDR and Hes5 repressed the 5-HT1A receptor gene, the repressor activity of NUDR was the most sensitive to the $\mathrm{C}(-1019) \mathrm{G}$ polymorphism associated with depression, and NUDR was the major factor bound to the $\mathrm{C}(-1019)$ site in nuclear extracts from serotonergic raphe neurons. In rat RN46A raphe cells, NUDR repressed both human and rat (data not shown) 5-HT1A promoter-luciferase constructs. Importantly, stable expression of NUDR greatly reduced the expression and binding of endogenous 5-HT1A receptors and RNA, indicating that NUDR negatively regulates both 5-HT1A gene transcription and receptor expression. In the dorsal raphe nucleus and RN46A cells, NUDR protein is coexpressed with the 5-HT1A receptor and binds to the 5-HT1A promoter at the polymorphic TTCG site, implicating NUDR in 5-HT1A regulation in vivo as well as in RN46A cells. Because RN46A cells were originally derived from E13 raphe neurons (White et al., 1994) and NUDR is also expressed in adult brain (LeBoeuf et al., 1998), NUDR may repress the 5-HT1A receptor gene throughout development and into adulthood. Because NUDR immunoreactivity is also present postsynaptically in 5-HT1A-expressing hippocampal and cortical neurons, derepression of the 5-HT1A gene should be induced by the G(-1019) allele in these cells; however, NUDR can act as a repressor or an enhancer, depending on cell type and promoter sequence (Huggenvik et al., 1998; Bottomley et al., 2001). Interestingly, our preliminary results suggest that NUDR enhances rather than represses 5-HT1A transcriptional activity in various hippocampal and septal cells (data not shown). Thus the G(-1019) allele derepresses 5-HT1A transcription presynaptically, but may have the opposite effect to reduce NUDRenhanced 5-HT1A transcription in postsynaptic cells. The net effect of these changes would be a reduction in serotonergic neurotransmission.

The role of Hes5 in regulating 5-HT1A receptor expression in vivo is less clear. Hes 5 may be involved in developmental regula- tion of 5-HT1A receptor expression, because Hes5 RNA is strongly expressed in the embryonic nervous system and declines in the adult (Akazawa et al., 1992). Interestingly, in early postnatal development Hes5 RNA is expressed in a subpopulation of cells of the hippocampal dentate gyrus and subventricular zone and in the cortex (Stump et al., 2002). As an important mediator of Notch signaling (Kageyama and Ohtsuka, 1999), Hes5induced repression could be important for the actions of Notch1 to inhibit dendritic elongation and promote branching (Sestan et al., 1999; Redmond et al., 2000). Hes5-mediated repression of 5-HT1A expression would be expected to reduce inhibitory somatodendritic signaling of the 5-HT1A receptor.

To assess more directly its role in the regulation of the 5-HT1A receptor in vivo, raphe-specific transgenic expression or gene knock-out of NUDR will be necessary. Because the C(-1019)G polymorphism is not present in rat or mouse genes, direct assessment of its function in animals will be difficult. Ultimately, it will be important to correlate this polymorphism with the level of 5-HT1A receptor expression in human patients. To date, it has been difficult to address whether gene regulatory polymorphisms result in altered expression of the protein product in human tissue. For example, although the 5-HT transporter promoter polymorphism was identified as functional in transformed human lymphoblasts (Lesch et al., 1996), a significant correlation between the polymorphism and 5-HT transporter protein expression in human postmortem tissues has not been reported (Mann et al., 2000). This undoubtedly reflects in part the complex nature of gene regulation in vivo (via multiple enhancers, repressors, and hormone response elements) and the presence of compensatory mechanisms (e.g., desensitization) that are recruited to normalize expression; however, the recent demonstration that people with this 5-HT transporter polymorphism show enhanced amygdala metabolism in response to aversive stimuli (Hariri et al., 2002) highlights the significant neurological consequences that can result from small promoter variations.

The level of expression of the 5-HT1A receptor has been implicated in mental illnesses (Blier and de Montigny, 1994; Albert et al., 1996; Artigas et al., 1996). Reduction of forebrain 5-HT1A receptor expression is correlated with anxiety, as seen in 5-HT1A gene knock-out mice that display anxiety-like behaviors (Heisler et al., 1998; Parks et al., 1998; Ramboz et al., 1998). Inducible expression of 5-HT1A receptors in the forebrain of 5-HT1A-/mice between postnatal days 5 and 21 was sufficient to restore anxiety-like behavior to normal (Gross et al., 2002), indicating the importance of developmental regulation of 5-HT1A receptors. Conversely, a specific increase in midbrain raphe 5-HT1A autoreceptors is correlated with depression and suicide (Stockmeier et al., 1998). Furthermore, downregulation or antagonism of the 5-HT1A autoreceptor by coadministration of pindolol enhances the clinical efficacy of antidepressant treatments (Artigas et al., 2001); however, recent positron emission tomography studies using the 5 -HT1A antagonist ${ }^{11} \mathrm{C}$-WAY100,635 suggest that 5-HT1A receptors may be reduced in patients with bipolar rather than unipolar depression. Technical issues of image acquisition, data analysis, and study design have contributed to some of the apparent inconsistencies across studies (Mann et al., 1996; Lowther et al., 1997; Mann, 1999; Drevets et al., 2000; Sargent et al., 2000). Another recent study reported a $43 \%$ decrease in 5-HT1A autoreceptor number in the midbrain of depressed suicide victims compared with controls (Arango et al., 2001); however, this decrease was possibly caused by a reduction in raphe cell number, which would decrease serotonergic neurotransmission. These disparate findings in depressed patients almost certainly 
reflect the heterogeneity of the disorder and the fact that an increase in 5-HT1A autoreceptors is only one of multiple mechanisms that can contribute to a decrease in serotonergic transmission that is associated with depression. Our results are consistent with a model that predicts that incorporation of the $\mathrm{C}(-1019) \mathrm{G}$ change would result in derepression of the 5-HT1A receptor gene in serotonergic raphe cells, leading to overexpression of the 5-HT1A autoreceptor to reduce serotonergic neurotransmission (Albert et al., 1996) (Fig. 7). The association of the G(-1019) allele with major depression and suicide suggests that impaired repression of the 5-HT1A receptor could contribute to a predisposition toward unipolar depression and its most severe outcome; however, further studies are needed to better characterize the association of the G(-1019) polymorphism with additional mental illnesses or behavioral phenotypes and its correlation with altered expression of the 5-HT1A receptor in vivo, or in postmortem tissues from depressed patients.

\section{References}

Akazawa C, Sasai Y, Nakanishi S, Kageyama R (1992) Molecular characterization of a rat negative regulator with a basic helix-loop-helix structure predominantly expressed in the developing nervous system. J Biol Chem 267:21879-21885.

Albert PR, Zhou QY, Van Tol HH, Bunzow JR, Civelli O (1990) Cloning, functional expression, and mRNA tissue distribution of the rat 5-hydroxytryptamine1A receptor gene. J Biol Chem 265:5825-5832.

Albert PR, Lembo P, Storring JM, Charest A, Saucier C (1996) The 5-HT1A receptor: signaling, desensitization, and gene transcription. Neuropsychopharmacology 14:19-25.

Arango V, Underwood MD, Boldrini M, Tamir H, Kassir SA, Hsiung S, Chen JJ, Mann JJ (2001) Serotonin 1A receptors, serotonin transporter binding and serotonin transporter mRNA expression in the brainstem of depressed suicide victims. Neuropsychopharmacology 25:892-903.

Arias B, Arranz MJ, Gasto C, Catalan R, Pintor L, Gutierrez B, Kerwin RW, Fananas L (2002) Analysis of structural polymorphisms and C-1018G promoter variant of the 5-HT(1A) receptor gene as putative risk factors in major depression. Mol Psychiatry 7:930-932.

Artigas F, Romero L, de Montigny C, Blier P (1996) Acceleration of the effect of selected antidepressant drugs in major depression by 5-htla antagonists. Trends Neurosci 19:378-383.

Artigas F, Celada P, Laruelle M, Adell A (2001) How does pindolol improve antidepressant action? Trends Pharmacol Sci 22:224-228.

Banker GA, Cowan WM (1977) Rat hippocampal neurons in dispersed cell culture. Brain Res 126:397-442.

Bengel D, Greenberg BD, Cora-Locatelli G, Altemus M, Heils A, Li Q, Murphy DL (1999) Association of the serotonin transporter promoter regulatory region polymorphism and obsessive-compulsive disorder. Mol Psychiatry 4:463-466.

Blier P, de Montigny C (1994) Current advances and trends in the treatment of depression. Trends Pharmacol Sci 15:220-226.

Bottomley MJ, Collard MW, Huggenvik JI, Liu Z, Gibson TJ, Sattler M (2001) The SAND domain structure defines a novel DNA-binding fold in transcriptional regulation. Nat Struct Biol 8:626-633.

Bown CD, Wang JF, Young LT (2003) Attenuation of N-methyl-Daspartate-mediated cytoplasmic vacuolization in primary rat hippocampal neurons by mood stabilizers. Neuroscience 117:949-955.

Brewer GJ, Torricelli JR, Evege EK, Price PJ (1993) Optimized survival of hippocampal neurons in B27-supplemented Neurobasal, a new serumfree medium combination. J Neurosci Res 35:567-576.

Chalmers DT, Watson SJ (1991) Comparative anatomical distribution of 5-HT1A receptor mRNA and 5-HT1A binding in rat brain-a combined in situ hybridization/in vitro receptor autoradiographic study. Brain Res 561:51-60.

Dichter MA (1978) Rat cortical neurons in cell culture: culture methods, cell morphology, electrophysiology, and synapse formation. Brain Res 149:279-293.

Doris A, Ebmeier K, Shajahan P (1999) Depressive illness. Lancet 354:1369-1375.

Drevets WC, Frank E, Price JC, Kupfer DJ, Greer PJ, Mathis C (2000) Sero- tonin type-1A receptor imaging in depression. Nucl Med Biol 27:499-507.

Du L, Faludi G, Palkovits M, Demeter E, Bakish D, Lapierre YD, Sotonyi P, Hrdina PD (1999) Frequency of long allele in serotonin transporter gene is increased in depressed suicide victims. Biol Psychiatry 46:196-201.

Du L, Bakish D, Lapierre YD, Ravindran AV, Hrdina PD (2000) Association of polymorphism of serotonin $2 \mathrm{~A}$ receptor gene with suicidal ideation in major depressive disorder. Am J Med Genet 96:56-60.

Duttweiler HM (1996) A highly sensitive and non-lethal beta-galactosidase plate assay for yeast. Trends Genet 12:340-341.

Eaton MJ, Staley JK, Globus MY, Whittemore SR (1995) Developmental regulation of early serotonergic neuronal differentiation: the role of brain-derived neurotrophic factor and membrane depolarization. Dev Biol 170:169-182.

Erdmann J, Shimron-Abarbanell D, Cichon S, Albus M, Maier W, Lichtermann D, Minges J, Reuner U, Franzek E, Ertl MA, Hebebrand J, Remschmidt H, Lehmkuhl G, Poustka F, Schmidt M, Fimmers R, Körner J, Rietschel M, Propping P, Nöthen MM (1995) Systematic screening for mutations in the promoter and the coding region of the 5-HT1A gene. Am J Med Genet 60:393-399.

Gross C, Zhuang X, Stark K, Ramboz S, Oosting R, Kirby L, Santarelli L, Beck S, Hen R (2002) Serotonin 1 A receptor acts during development to establish normal anxiety-like behaviour in the adult. Nature 416:396-400.

Gross CT, McGinnis W (1996) DEAF-1, a novel protein that binds an essential region in a Deformed response element. EMBO J 15:1961-1970.

Hariri AR, Mattay VS, Tessitore A, Kolachana B, Fera F, Goldman D, Egan MF, Weinberger DR (2002) Serotonin transporter genetic variation and the response of the human amygdala. Science 297:400-403.

Heisler LK, Chu HM, Brennan TJ, Danao JA, Bajwa P, Parsons LH, Tecott LH (1998) Elevated anxiety and antidepressant-like responses in serotonin 5-HT1A receptor mutant mice. Proc Natl Acad Sci USA 95:15049-15054.

Heyer E, Tremblay M (1995) Variability of the genetic contribution of Quebec population founders associated to some deleterious genes. Am J Hum Genet 56:970-978.

Huggenvik JI, Michelson RJ, Collard MW, Ziemba AJ, Gurley P, Mowen KA (1998) Characterization of a nuclear deformed epidermal autoregulatory factor-1 (DEAF-1)-related (NUDR) transcriptional regulator protein. Mol Endocrinol 12:1619-1639.

Hyman S (2000) Mental illness: genetically complex disorders of neural circuitry and neural communication. Neuron 28:321-323.

Jacobs BL, Azmitia EC (1992) Structure and function of the brain serotonin system. Physiol Rev 72:165-229.

Kageyama R, Ohtsuka T (1999) The Notch-Hes pathway in mammalian neural development. Cell Res 9:179-188.

Kawanishi Y, Harada S, Tachikawa H, Okubo T, Shiraishi H (1998) Novel mutations in the promoter and coding region of the human 5-HT1A receptor gene and association analysis in schizophrenia. Am J Med Genet 81:434-439.

LeBoeuf RD, Ban EM, Green MM, Stone AS, Propst SM, Blalock JE, Tauber JD (1998) Molecular cloning, sequence analysis, expression, and tissue distribution of suppressin, a novel suppressor of cell cycle entry. J Biol Chem 273:361-368.

Lembo PM, Albert PR (1995) Multiple phosphorylation sites are required for pathway-selective uncoupling of the 5-hydroxytryptamine 1A receptor by protein kinase C. Mol Pharmacol 48:1024-1029.

Lesage AD, Boyer R, Grunberg F, Vanier C, Morissette R, Menard-Buteau C, Loyer M (1994) Suicide and mental disorders: a case-control study of young men. Am J Psychiatry 151:1063-1068.

Lesch KP, Bengel D, Heils A, Sabol SZ, Greenberg BD, Petri S, Benjamin J, Muller CR, Hamer DH, Murphy DL (1996) Association of anxietyrelated traits with a polymorphism in the serotonin transporter gene regulatory region. Science 274:1527-1531.

Lowther S, De Paermentier F, Cheetham SC, Crompton MR, Katona CL, Horton RW (1997) 5-HT1A receptor binding sites in post mortem brain samples from depressed suicides and controls. J Affect Disord 42:199-207.

MacKenzie A, Quinn J (1999) A serotonin transporter gene intron 2 polymorphic region, correlated with affective disorders, has allele-dependent differential enhancer-like properties in the mouse embryo. Proc Natl Acad Sci USA 96:15251-15255.

Mann JJ (1999) Role of the serotonergic system in the pathogenesis of major 
depression and suicidal behavior. Neuropsychopharmacology 21:99S-105S.

Mann JJ, Brent DA, Arango V (2001) The neurobiology and genetics of suicide and attempted suicide: a focus on the serotonergic system. Neuropsychopharmacology 24:467-477.

Mann JJ, Malone KM, Diehl DJ, Perel J, Cooper TB, Mintun MA (1996) Demonstration in vivo of reduced serotonin responsivity in the brain of untreated depressed patients. Am J Psychiatry 153:174-182.

Mann JJ, Huang YY, Underwood MD, Kassir SA, Oppenheim S, Kelly TM, Dwork AJ, Arango V (2000) A serotonin transporter gene promoter polymorphism (5-HTTLPR) and prefrontal cortical binding in major depression and suicide. Arch Gen Psychiatry 57:729-738.

Michelson RJ, Collard MW, Ziemba AJ, Persinger J, Bartholomew B, Huggenvik JI (1999) Nuclear DEAF-1-related (NUDR) protein contains a novel DNA binding domain and represses transcription of the heterogeneous nuclear ribonucleoprotein A2/B1 promoter. J Biol Chem 274:30510-30519.

Mongeau R, Blier P, de Montigny C (1997) The serotonergic and noradrenergic systems of the hippocampus: their interactions and the effects of antidepressant treatments. Brain Res Brain Res Rev 23:145-195.

Nakhai B, Nielsen DA, Linnoila M, Goldman D (1995) Two naturally occurring amino acid substitutions in the human 5-HT1A receptor: glycine 22 to serine 22 and isoleucine 28 to valine 28 . Biochem Biophys Res Commun 210:530-536.

Nestler EJ, Barrot M, DiLeone RJ, Eisch AJ, Gold SJ, Monteggia LM (2002) Neurobiology of depression. Neuron 34:13-25.

Ou XM, Jafar-Nejad H, Storring JM, Meng JH, Lemonde S, Albert PR (2000) Novel dual repressor elements for neuronal cell-specific transcription of the rat 5-HT1A receptor gene. J Biol Chem 275:8161-8168.

Parks CL, Shenk T (1996) The serotonin 1a receptor gene contains a TATAless promoter that responds to MAZ and Sp1. J Biol Chem 271:4417-4430.

Parks CL, Robinson PS, Sibille E, Shenk T, Toth M (1998) Increased anxiety of mice lacking the serotonin 1A receptor. Proc Natl Acad Sci USA 95:10734-10739.

Pineyro G, Blier P (1999) Autoregulation of serotonin neurons: role in antidepressant drug action. Pharmacol Rev 51:533-591.

Pompeiano M, Palacios JM, Mengod G (1992) Distribution and cellular localization of mRNA coding for 5-HT1A receptor in the rat brain: correlation with receptor binding. J Neurosci 12:440-453.

Ramboz S, Oosting R, Amara DA, Kung HF, Blier P, Mendelsohn M, Mann JJ, Brunner D, Hen R (1998) Serotonin receptor 1A knockout: an animal model of anxiety-related disorder. Proc Natl Acad Sci USA 95:14476-14481.

Redmond L, Oh SR, Hicks C, Weinmaster G, Ghosh A (2000) Nuclear Notch 1 signaling and the regulation of dendritic development. Nat Neurosci 3:30-40.

Sargent PA, Kjaer KH, Bench CJ, Rabiner EA, Messa C, Meyer J, Gunn RN, Grasby PM, Cowen PJ (2000) Brain serotonin 1A receptor binding measured by positron emission tomography with $\left[{ }^{11} \mathrm{C}\right]$ WAY-100635: effects of depression and antidepressant treatment. Arch Gen Psychiatry 57:174-180.

Sestan N, Artavanis-Tsakonas S, Rakic P (1999) Contact-dependent inhibition of cortical neurite growth mediated by notch signaling. Science 286:741-746.

Spitzer RL, Williams JB, Gibbon M, First MB (1992) The structured clinical interview for DSM-III-R (SCID). I: History, rationale, and description. Arch Gen Psychiatry 49:624-629.

Stockmeier CA, Shapiro LA, Dilley GE, Kolli TN, Friedman L, Rajkowska G (1998) Increase in serotonin-1A autoreceptors in the midbrain of suicide victims with major depression: postmortem evidence for decreased serotonin activity. J Neurosci 18:7394-7401.

Storring JM, Charest A, Cheng P, Albert PR (1999) TATA-driven transcriptional initiation and regulation of the rat serotonin 5-HT1A receptor gene. J Neurochem 72:2238-2247.

Stump G, Durrer A, Klein AL, LutolfS, Suter U, Taylor V (2002) Notch1 and its ligands Delta-like and Jagged are expressed and active in distinct cell populations in the postnatal mouse brain. Mech Dev 114:153-159.

Sugihara TM, Bach I, Kioussi C, Rosenfeld MG, Andersen B (1998) Mouse deformed epidermal autoregulatory factor 1 recruits a LIM domain factor, LMO-4, and CLIM coregulators. Proc Natl Acad Sci USA 95:15418-15423.

Törk I (1990) Anatomy of the serotonergic system. Ann NY Acad Sci 600:9-34

Verdot L, Bertin B, Guilloteau D, Strosberg AD, Hoebeke J (1995) Characterization of pharmacologically active anti-peptide antibodies directed against the first and second extracellular loops of the serotonin 5-HT1A receptor. J Neurochem 65:319-328.

White LA, Eaton MJ, Castro MC, Klose KJ, Globus MY, Shaw G, Whittemore SR (1994) Distinct regulatory pathways control neurofilament expression and neurotransmitter synthesis in immortalized serotonergic neurons. J Neurosci 14:6744-6753.

Wu S, Comings DE (1999) A common C-1018G polymorphism in the human 5-HT1A receptor gene. Psychiatr Genet 9:105-106. 